\title{
SENSIBILIDADE DAS CULTURAS DA BATATA (Solanum tuberosum L.) E DA ALFACE (Lactuca sativa L.) AO EXCESSO DE ÁGUA NO SOLO
}

\author{
Pablo Alberto Núñez Flecha
}

\begin{abstract}
Dissertação apresentada à Escola Superior de Agricultura "Luiz de Queiroz", da Universidade de São Paulo, para obtenção do título de Mestre em Agronomia, Área de Concentração: Irrigação e Drenagem.
\end{abstract}

P I R A C I C A B A

Estado de São Paulo - Brasil

Fevereiro - 2004 


\title{
SENSIBILIDADE DAS CULTURAS DA BATATA (Solanum tuberosum L.) E DA ALFACE (Lactuca sativa L.) AO EXCESSO DE ÁGUA NO SOLO
}

\author{
PABLO ALBERTO NÚÑEZ FLECHA \\ Engenheiro Agônomo
}

Orientador: Prof. Dr. SERGIO NASCIMENTO DUARTE

Dissertação apresentada à Escola Superior de Agricultura “Luiz de Queiroz”, da Universidade de São Paulo, para obtenção do título de Mestre em Agronomia, Área de Concentração: Irrigação e Drenagem.

P I R A C I C A B A

Estado de São Paulo - Brasil

Fevereiro - 2004 


\section{Dados Internacionais de Catalogação na Publicação (CIP) DIVISÃO DE BIBLIOTECA E DOCUMENTAÇÃO - ESALQ/USP}

Núñez Flecha, Pablo Alberto

Sensibilidade das culturas da batata (Solanum tuberosum L.) e da alface (Lactuca sativa L.) ao excesso de água no solo / Pablo Alberto Núñez Flecha. - - Piracicaba, 2004.

68 p. : il.

Dissertação (mestrado) - - Escola Superior de Agricultura Luiz de Queiroz, 2004.

Bibliografia.

1. Alface 2. Batata 3. Drenagem agrícola 4. Encharcamento 5. Lençol freático Título

CDD 633.491

"Permitida a cópia total ou parcial deste documento, desde que citada a fonte - O autor" 
Aos meus pais Elva Paulina e Prudencio in memorian, Pelo amor, carinho e apoio infinito

Aos meus irmãos Abdón, Blanca e Gerardo

e a todos os meus sobrinhos

Ofereço

A minha esposa María Esther e ao meu filho Mathías Sebastián

Amores da minha vida

Dedico 


\section{AGRADECIMENTOS}

A Deus, pela vida ;

Ao professor Sergio Nascimento Duarte, grande mestre e amigo, pela orientação e incondicional apoio;

Ao Mestre em Agronomia Alfredo Salinas Daiub, pela amizade e incentivo para a realização deste Curso de Pós-Graduação;

Aos professores do Departamento de Engenharia Rural e em especial ao professor Jarbas Honório de Miranda do Departamento de Ciências Exatas da ESALQ pelas sugestões e ensinamentos;

Ao professor Dr. Marcos Vinícius Folegatti pela coordenação do Curso de PósGraduação em Irrigação e Drenagem da ESALQ/USP;

Aos senhores Antonio, Gilmar, Hélio e César e às senhoras Davilmar, Vanda e Sandra, funcionários do Departamento de Engenharia Rural, pela amizade e ajuda indispensável em todos os momentos;

Ao acadêmico do Curso de Engenharia Agronômica da ESALQ, Rafael Mingoti pela colaboração prestada na realização das análises estatísticas;

Aos pesquisadores Doutores Hilario S. Miranda Filho e Newton P. Granja do Setor de Raízes e Tubérculos do Instituto Agronômico de Campinas, pela amizade, sugestões e provisão das batatas sementes;

Ao professor Dr. Octávio Nakano e seus colaboradores, pela ajuda na identificação das pragas e provisão dos defensivos; 
Ao amigo Dr. Isao Ishimura, Diretor da Estação Experimental São Roque do Instituto Agronômico de Campinas pela motivação para a realização deste Curso;

Ao Ministerio de Agricultura y Ganaderia do Paraguai pela liberação e apoio;

À Coordenação de Aperfeiçoamento de Pessoal de Nível Superior CAPES, pela bolsa de estudo concedida durante o Curso;

Ao Departamento de Engenharia Rural da ESALQ pelo apoio financeiro ao trabalho de pesquisa;

Aos colegas de Curso Juan Rojas, Manuel Navarro, Walter Geremías, Marcelo de Novaes, Ariovaldo Tadeu Lucas, José Roberto, Jocelito de Sá, Adriano, Luís Faria, Rodrigo e aos demais pós-graduandos, pela amizade, companheirismo e bom convívio ;

Aos amigos Ramón Martínez, Valeria Modolo, Norma Migone, Noemí Anido, Alice Aranda, Nicolás Zárate, Verónica, Patricia, Elizabeth, René Chipana, Rubén Franco, Ricardo Klugue, Myriam, Moisés González, Ingrid, Soraia Franca e Raf, e aos demais integrantes e aderentes da coletividade estrangeira da ESALQ, pela amizade, apoio, compreensão e os gratos momentos compartilhados;

Aos colegas do Ministerio de Agricultura y Ganaderia do Paraguai pela colaboração e convívio amigo;

Aos meus queridos sogros Filemón e Primitiva Delia pelo carinho, tolerância e cooperação. 


\section{SUMÁRIO}

LISTA DE FIGURAS............................................................................. viii

LISTA DE TABELAS...................................................................... $\quad$ X

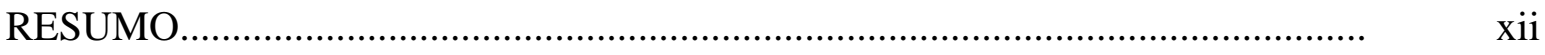

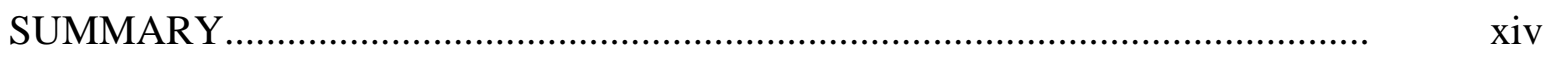

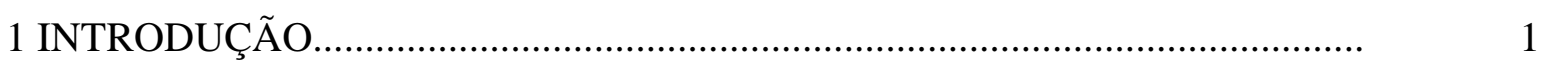

2 REVISÃO DE LITERATURA................................................................. 4

2.1 Excesso de umidade no solo e seus efeitos..................................................

2.2 Objetivos e critérios da drenagem agrícola................................................... 8

2.3 Resposta das culturas à profundidade do lençol freático.................................. 9

2.4 Dinâmica do lençol freático e tolerância das culturas......................................

2.5 Relação entre a produtividade das culturas e o índice diário de estresse

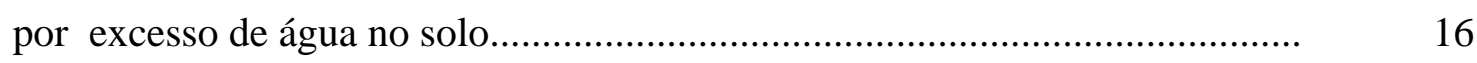

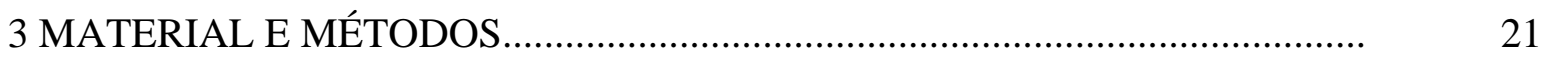

3.1 Local e estrutura das parcelas experimentais.............................................. 21

3.2 Sistema de alimentação e drenagem dos recipientes..................................... 22

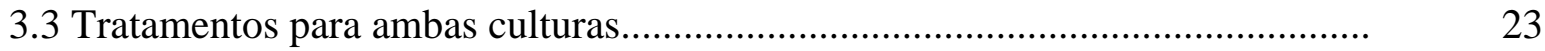

3.4 Cálculo das profundidades intermediárias do lençol freático........................... 25

3.5 Controle do nível do lençol freático............................................................ 27

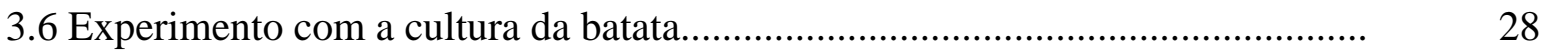

3.6.1 Amostragem do solo, análise do solo e adubação........................................ 28

3.6.2 Variedade e época de plantio.................................................................... 29

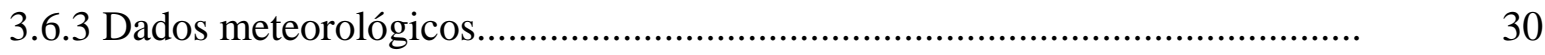

3.6.4 Manejo da Irrigação........................................................................... 


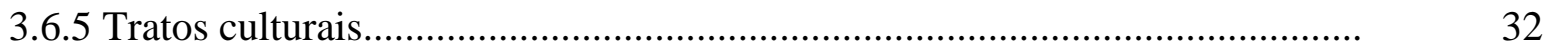

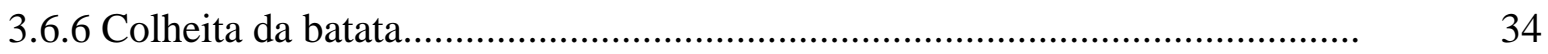

3.6.7 Tratamentos e delineamento experimental para a cultura da batata............... 34

3.6.8 Avaliação dos parâmetos relativos à produção da batata................................ 35

3.6.9 Relação entre a produtividade relativa da batata e o índice diário de

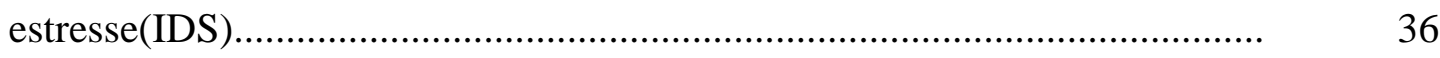

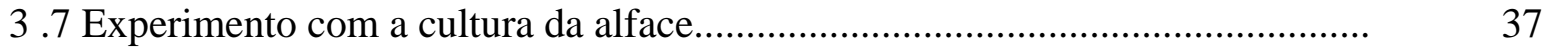

3.7.1 Amostragem do solo, análise do solo e adubação......................................

3.7.2 Variedade e época de plantio.................................................................

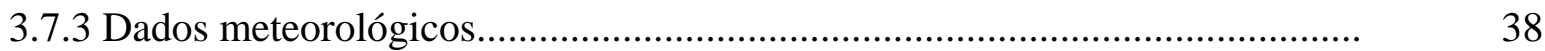

3.7.4 Manejo da Irrigação........................................................................... 38

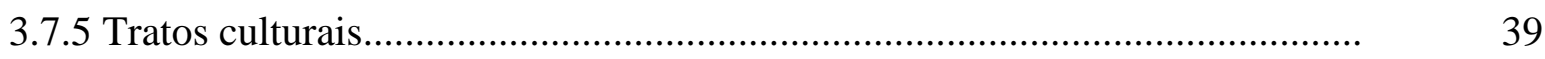

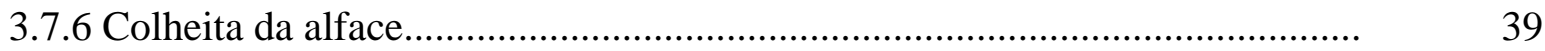

3.7.7 Tratamentos e delineamento experimental para a cultura da alface................ 40

3.7.8 Avaliação dos parâmetros vegetativos e da produção da alface...................... 41

3.7.9 Relação entre a produtividade relativa da alface e o índice diário de

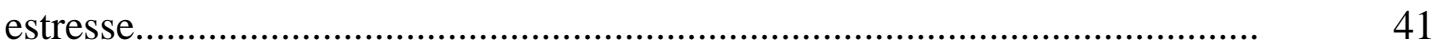

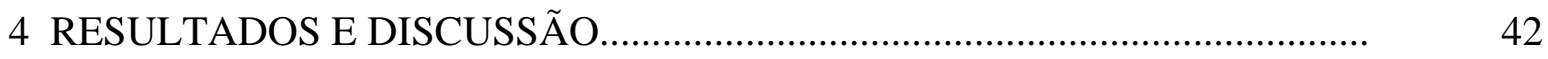

4.1 Experimento com a cultura da batata...................................................... 42

4.1.1 Parâmetros climáticos medidos ao longo do ciclo da batata........................... 42

4.1.2 Produtividade da batata e seus componentes............................................. 43

4.1.3 Relação entre a produtividade relativa da cultura da batata e o índice diário de estresse (IDS) ....................................................................... 49

4.2 Experimento com a cultura da alface....................................................... 51

4.2.1Parâmetros climáticos medidos ao longo do ciclo da alface.......................... 51

4.2.2 Variáveis fenológicas e produtividade da alface........................................ 52

4.2.3 Relação entre a produtividade relativa da cultura da alface e o índice diário de estresse (IDS) ....................................................................... 57

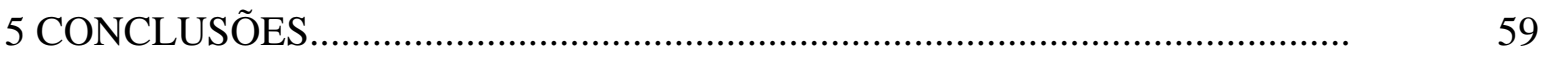

REFERÊNCIAS BIBLIOGRÁFICAS......................................................... 60 


\section{LISTA DE FIGURAS}

Página

1 Vista panorâmica da área experimental durante o ciclo da cultura da ba-

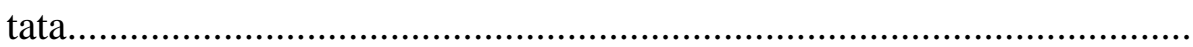

10 Médias do peso verde de tubérculos sadios graúdos (diâmetro mínimo $>45 \mathrm{~mm}$ ), por planta de batata, segundo os diferentes tratamentos 
11 Médias do peso verde de tubérculos sadios com diâmetro mínimo $<20 \mathrm{~mm}$, por planta de batata, segundo os diferentes tratamen-

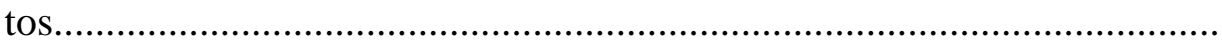

12 Produtividade comercial da batata (YT) relacionada ao índice diário de estresse (IDS)

13 Médias da altura da parte aérea das plantas de alface segundo os diferentes tratamentos

14 Médias do diâmetro da “cabeça” das plantas de alface segundo os diferentes tratamentos.

15 Médias do diâmetro do caule das plantas de alface segundo os diferentes tratamentos

16 Médias do peso verde da parte aérea das plantas de alface segundo os

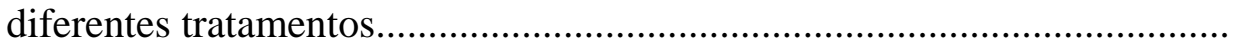

17 Médias do peso seco da parte aérea das plantas de alface segundo os di-

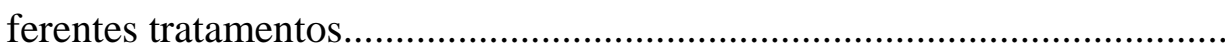

18 Peso verde relativo da parte aérea da alface (YT) relacionado ao índice diário de estresse (IDS) 


\section{LISTA DE TABELAS}

Página

1 Profundidade crítica do lençol freático para condições de chuva, segundo

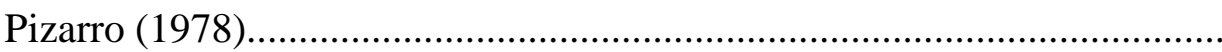

2 Profundidades do lençol freático $(\mathrm{cm})$ em função do tempo, para diferentes velocidades de rebaixamento.

3 Análise química do solo utilizado no experimento com a cultura da batata.

4 Relação dos parâmetros do material de solo utilizado, para a entrada no modelo de van Genuchten (1980), segundo Miranda (2001)......................

5 Esquema de pulverizações realizadas durante o ciclo da cultura da batata.

6 Esquema da análise de variância utilizada para a cultura da batata............

7 Classificação comercial dos tubérculos, segundo a Portaria $n^{0} 307$ do Ministério da Agricultura (EMBRATER, 1982)........................................

8 Análise química do solo utilizado no experimento com a cultura da alface.

9 Esquema da análise de variância utilizada para o experimento com a cultura da alface.

10 Parâmetros climáticos medidos ao longo do ciclo da batata. 
11 Valores de $\mathrm{F}$ e da probabilidade do efeito ter se dado ao acaso para as variáveis peso verde total de tubérculos (PVT), peso seco total de tubérculos (PST), número total de tubérculos (NT), peso verde de tubérculos sadios (PVS) e peso verde comercial de tubérculos

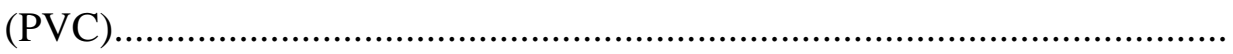

12 Valores de F e da probabilidade do efeito ter se dado ao acaso para o peso verde de tubérculos sadios, segundo o menor diâmetro das diferen-

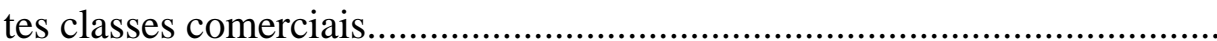

13 Parâmetros climáticos medidos ao longo do ciclo da alface.......................

14 Valores de F e da probabilidade do efeito ter se dado ao acaso para cada variável avaliada no experimento com a alface......................................... 


\title{
SENSIBILIDADE DAS CULTURAS DA BATATA (Solanum tuberosum L.) E DA ALFACE (Lactuca sativa L.) AO EXCESSO DE ÁGUA NO SOLO
}

\author{
Autor: PABLO ALBERTO NÚÑEZ FLECHA \\ Orientador: Prof. Dr. SERGIO NASCIMENTO DUARTE
}

\section{RESUMO}

O trabalho teve como objetivos determinar os efeitos de inundações do sistema radicular em diferentes estádios de desenvolvimento sobre a produtividade das culturas da batata e da alface, identificar a velocidade mínima de rebaixamento do nível freático capaz de evitar prejuízos a estas culturas e obter relações entre a produtividade relativa das mesmas e o índice diário de estresse por excesso de água no solo. Para tal foram conduzidos dois experimentos em lisímetros construídos a partir de tubos de concreto, considerados como parcelas, de julho a outubro de 2001 com a cultura da batata, e de dezembro de 2001 a janeiro de 2002 com a cultura da alface. O delineamento experimental adotado foi inteiramente casualizado, arranjado em esquema fatorial [( $\left.3 \times{ }^{4}\right)+$ 1], com quatro repetições para a cultura da batata e três repetições para a cultura da alface. Para ambas as culturas os tratamentos consistiram de 3 períodos de aplicação do encharcamento, 4 velocidades de rebaixamento do nível freático (30 cm em 24, 48, 72 e 96 horas), mais uma testemunha na qual não foi aplicado estresse por elevação do nível freático. A análise dos resultados revelou que dentre os três estádios nos quais o estresse foi aplicado, o que ocasionou maiores perdas para a cultura da batata foi o terceiro (aplicado do $85^{\circ}$ ao $88^{\circ}$ dia após o plantio), enquanto que para a cultura da alface o estádio 
mais crítico foi o primeiro (aplicado do $12^{\circ}$ ao $15^{\circ}$ dia após o transplantio) . Não foi possível determinar a velocidade de rebaixamento do nível freático mais adequada, pois mesmo com a maior velocidade testada (30 cm em 24 horas), houve decréscimos de cerca de 50\% da produtividade, para ambas as culturas. Foram obtidas correlações lineares negativas entre as produtividades relativas de ambas as culturas e o índice diário de estresse por excesso de água no solo. 


\title{
POTATO (Solanum tuberosum L.) AND LETTUCE (Lactuca sativa L.) SENSIBILITY TO WATER EXCESS IN SOIL
}

\author{
Author: PABLO ALBERTO NÚÑEZ FLECHA \\ Adviser: Prof. Dr. SERGIO NASCIMENTO DUARTE
}

\section{SUMMARY}

This work had as objectivies determinating the effects of root system flooding in three stages of growing of potato and lettuce crops, identifying the minimum watertable drawdown velocity necessary to avoid yield reductions and obtaining relations between relative yield and stress day index caused by excess of water in the soil. For these purposes two experiments were conducted in lisimeters, buit with concrete pipe, considered as parcels, from july to october of 2001, with potato crop, and from december of 2001 to january of 2002, with lettuce crop. The statistical experimental design was a complete randomizer in a factorial arrangement $[(3 \times 4)+1]$, with four replications for potato crop and three replications for lettuce crop. For both crops the treatment consisted in 3 growing stages of water-logging application, 4 drawdown velocities (30 cm during 24, 48, 72 and 96 hours) and a control in wich was not applied the stress of rising of the water-table. The results analysis showed that among the three stages where the water-logging were applied, the one who caused bigger yield reduction was the third (applied from the $85^{\text {th }}$ to the $88^{\text {th }}$ day after planting), for the potato crop and the first (applied from the $12^{\text {th }}$ to the $15^{\text {th }}$ day after re-planting), for the lettuce crop. It was not possible to identify the more adequate water-table drawdown velocity because even using the biggest velocity (30 cm during 24 horas) there were a 50\% yield reduction for both 
crops. The potato and the lettuce relative yields showed a negative linear relation with the stress day index. 


\section{INTRODUÇÃO}

Para fornecer informações que contribuam para dar um uso rentável a áreas com drenagem deficiente, é necessário realizar pesquisas em relação à tolerância das culturas ao excesso de água no solo. Conhecem-se atualmente diversas culturas, além das tradicionais, que apresentam certa tolerância ao encharcamento; essa sensibilidade pode ser avaliada com a determinação do tempo máximo de inundação capaz de ser suportado pela cultura sem que o mesmo atue significativamente na fase de crescimento da mesma ou cause prejuízos na produção.

Existem inúmeros trabalhos relacionados a este tipo de pesquisa, sendo de grande importância nas situações em que não se tem a possibilidade de cultivar uma espécie vegetal adaptada a condições de excesso de umidade. Seja a razão de cunho político, econômico, social ou cultural, é necessário se dispor de dados referentes ao comportamento da cultura com relação ao alagamento do solo para que a produção possa ser viabilizada. Esses dados somente serão de ajuda, nos projetos de drenagem, se forem disponíveis em termos quantitativos.

Como alguns autores afirmam, os dados sobre respostas de uma cultura ao excesso de água no solo só podem ser usados como referência para o desenvolvimento de projetos de drenagem em situações semelhantes, devido ao fato de que esses dados não são extrapoláveis para diferentes culturas, estádios fenológicos de desenvolvimento, variedades e condições edafoclimáticas; isto porque as espécies vegetais variam suas respostas a esse tipo de estresse de acordo com suas características intrínsecas e as condições externas locais (solo e clima).

O problema se agrava nas regiões onde a lavoura das várzeas é a única possibilidade de produção agrícola, utilizando padrões de cultura adaptados a pequenas propri- 
edades, já que o agricultor minifundiário muitas vezes não pode optar pelo cultivo do arroz, devido aos custos elevados de sistematização do terreno, de produção da cultura e a necessidade de máquinas especiais para a colheita, equipamentos para a conservação de grãos e industrialização. Além disso, há falta de infra-estrutura adequada e de mão de obra qualificada para o desenvolvimento de pesquisas avançadas, na tentativa de cobrir a falta de informação sobre a sensibilidade das culturas ao encharcamento, item fundamental para o dimensionamento de sistemas de drenagem, na medida em que origina os coeficientes de drenagem das culturas a serem utilizados nas equações disponíveis para o dimensionamento do espaçamento entre drenos.

Há que se considerar também o elevado custo de escavação por metro cúbico de solo, onde interferem os custos horários da máquina, a habilidade dos operadores, o tipo do solo (tanto para a mobilidade da máquina quanto para o desgaste das peças de rolamento e articulação), a distância entre o canteiro de obras e os acampamentos, além dos custos de elaboração de projetos e também dos drenos tubulares, caso se opte pela utilização dos mesmos.

A principio, o critério utilizado para uma drenagem efetiva é que os espaçamentos, as profundidades e as seções dos drenos adotados não acarretem diminuição na produtividade da cultura, não sendo necessariamente este critério o que dará a melhor relação beneficio/custo ao projeto. Dispondo-se de dados de sensibilidade da cultura ao tempo de inundação do solo e de um modelo hidrológico de simulação, pode-se alterar a intensidade da drenagem para a cultura em questão, a fim de se determinar as alternativas que fornecem a maior relação beneficio/custo do projeto.

Segundo alguns autores, as áreas de várzea possuem a potencialidade de produção de hortaliças, principalmente no inverno, já que nessa época, na região Sudeste do Brasil, o lençol freático está mais baixo. Sabe-se que as espécies hortícolas possuem importante valor comercial, em qualquer país do mundo, pelo seu valor nutricional, o que as qualifica como gênero alimentício de primeira necessidade. Dentre essas, a batata e a alface são duas das mais populares no mundo inteiro e são muito importantes do ponto de vista econômico. Para ambas as culturas a água é um dos fatores mais críticos para o desenvolvimento e produtividade. 
Muitos autores afirmam que a cultura da batata é muito sensível à falta de oxigênio na região ativa das raízes, exigindo uma drenagem eficiente para atenuar os efeitos das inundações. Por outro lado dispõe-se de poucos dados na literatura a respeito da sensibilidade da cultura da alface.

Pela necessidade de se obter dados experimentais locais que tratem da influência do encharcamento na produção dessas culturas, e utilizando-se uma metodologia simples, de infra-estrutura de baixo custo, capaz de ser aplicável em regiões com problemas de drenagem pouco desenvolvidas, como a região Sudoeste do Paraguai, onde se possa montar experimentos similares para gerar informações in situ e com as culturas importantes para a região, objetivou-se com o presente trabalho obter informações básicas, sob condições locais de clima e solo para quantificar:

- Os efeitos de inundações periódicas do sistema radicular em diferentes estádios do ciclo de uma cultura de batata (Solanum tuberosum L.) e de uma cultura de alface (Lactuca sativa L.).

- A velocidade mínima de rebaixamento do lençol freático capaz de evitar prejuízos à cultura, visando à determinação do coeficiente de drenagem a ser utilizado em projetos.

- As relações existentes entre a produtividade relativa destas culturas e o índice diário de estresse, relações estas necessárias ao emprego de modelos de simulação de desempenho de sistemas de drenagem. 


\section{REVISÃO DE LITERATURA}

\subsection{Excesso de umidade no solo e seus efeitos sobre as culturas}

Do ponto de vista agronômico, o solo é um meio poroso onde se conjugam as fases sólida (matéria orgânica e minerais), líquida e gasosa, que fornecem à planta oxigênio e nutrientes necessários para seu desenvolvimento. Para que se cumpra a interação entre esses componentes favoravelmente, os teores de água e oxigênio devem estar em proporções que favoreçam um ambiente ótimo para o crescimento vegetal (Coelho et al., 1988).

Segundo Reichardt (1985), a transferência interna do $\mathrm{O}_{2}$ das folhas para as raízes não se dá em proporções suficientes para suprir as necessidades de $\mathrm{O}_{2}$ nos tecidos das raízes na maioria das plantas, com exceção daquelas adaptadas como o arroz. Para um crescimento adequado, as raízes requerem um grau de aeração, de tal modo que o intercâmbio gasoso entre a atmosfera e o solo se dê em níveis suficientes para não permitir deficiências de $\mathrm{O}_{2}$, ou excesso de $\mathrm{CO}_{2}$.

As várzeas ou planícies de inundação constituem terrenos baixos e relativamente planos, localizados nas margens dos rios, ribeirões, lagos, e pântanos, sendo áreas propensas a inundações periódicas, em períodos de chuva, devido ao nível freático pouco

profundo, limitando dessa forma a exploração agronômica natural só a períodos não chuvosos do ano, ainda com algum risco devido a probabilidade de que ocorram enchentes extemporâneas em períodos de seca (Curi et al., 1988).

Basicamente os solos das várzeas de tipo Glei Húmico, Glei pouco Húmico, Orgânicos e Aluviais são denominados hidromórficos e originados de sedimentos provenientes de diversas fontes, com grande variabilidade horizontal e vertical dos horizontes, sendo uma característica importante a predisposição ao encharcamento súbito é à seca- 
gem rápida, derivados da flutuação do lençol freático. Essas áreas requerem um manejo delicado para não se drenar em excesso e originar mais problemas que reflitam num aumento de custos pela necessidade de implementar outras práticas agronômicas, além de se tentar manter um equilíbrio ambiental, minimizando as alterações do meio (Curi et al., 1988; Klamt et al., 1985).

Beltrán (1986) define o encharcamento como a saturação temporária do solo ocasionada por excessos de precipitações ou irrigações, ascensão capilar a partir do nível freático, inundações e presença de camadas superficiais compactadas, geralmente em solos com reduzida permeabilidade.

Com a saturação do solo, a respiração das raízes das plantas torna-se significativamente comprometida devido à diminuição ou falta de oxigênio. A atividade respiratória constitui uma das mais importantes e necessárias do metabolismo vegetal e com sua diminuição torna-se o fator mais importante para a redução do desenvolvimento das culturas. O suprimento do oxigênio utilizado na respiração vegetal em condições normais difunde-se do ar do solo até as raízes, fenômeno drasticamente reduzido quando ocorre a saturação do meio com água (Cruciani, 1981a).

Com o excesso de água, freqüentemente as condições do solo tornam-se adversas por duas razões: 1) deterioração do ar e das composições gasosas do solo e 2) redução do estoque e disponibilidade de substâncias nutritivas. A deterioração da composição gasosa do solo é caracterizada pela redução do oxigênio, resultando na formação de uma grande quantidade de compostos reduzidos, especialmente de manganês e ferro. Ocorre também o aumento da quantidade de $\mathrm{CO}_{2}$, e com isso o regime do cálcio se altera. $\mathrm{O}$ equilíbrio entre os hidróxidos, carbonatos e bicarbonatos de cálcio é mantido pelo ácido carbônico no solo. A quantidade de microorganismos aeróbicos do solo, que participam da oxidação do material orgânico, sofre diminuição. Em conseqüência da desintegração das substâncias orgânicas, ao invés dos produtos finais da respiração aeróbica $\left(\mathrm{CO}_{2}\right.$, nitratos, fosfatos, cálcio, magnésio, potássio, entre outros, compostos de metano, hidrogênio, sulfeto, amônia, aldeídos e formas mais reduzidas de compostos de ferro) observase a formação de nitritos, ácido carboxílico e etileno (Meyer, 1960). 
A concentração de Fe na solução aumenta rapidamente após a inundação do solo e atinge um valor máximo após duas a quatro semanas e depois decresce. Essa alta concentração de Fe influi como uma toxidez indireta, por reduzir a absorção de P, K, Ca e Mg pelas plantas (Bacha, 1987).

Quando a quantidade de $\mathrm{O}_{2}$ torna-se insuficiente devido ao excesso de água, a intensidade do processo de óxido-redução e a respiração abaixam e ocorre redução do nível de energia nas células radiculares. Ocorre também a diminuição da absorção de substâncias nutritivas. A capacidade de retenção de água pelas raízes aumenta, quando os meios de desidratação aplicados são insuficientes, e esta capacidade declina levemente, ao serem utilizados meios severos de desidratação, devido a redução da energia nas células das raízes e da movimentação e estrutura da água intercelular (Kozlowski, 1976)

A quantidade de etileno aumenta, fortalecida pela inundação. Por exemplo, em condições anaeróbicas, após 7 dias, a concentração de etileno varia de 9,3 a 10,6 mg kg-1 enquanto em condições aeróbicas, à profundidade do solo de $15 \mathrm{~cm}$, esta concentração é de $0,07 \mathrm{mg} \mathrm{kg}^{-1}$ e a uma profundidade do solo de $60 \mathrm{~cm}$, de $0,14 \mathrm{mg} \mathrm{kg}^{-1}$. A crescente concentração de etileno causa afinamento das hastes, senescência epinástica e queda das folhas (Lange, 1953; Nobel, 1974)

A deficiência de $\mathrm{O}_{2}$ causada pela inundação provoca alterações no estado de respiração das folhas e no nível de energia. É provavelmente uma resposta á adaptação, que tende a estabelecer um equilíbrio entre o balanço de energia na planta como um todo. A capacidade de retenção da água pelas folhas é reduzida e como resultado o regime de água se desorganiza, ocorrendo então a murcha, a senescência e a queda de folhas (Roberts, 1961). A natureza da respiração muda, aumenta uma parte relativa da respiração anaeróbica, tendo como produtos finais o etanol e o lactato. O grande acúmulo de etanol nas células causa a morte destas. As células podem eliminar o etanol liberando-o para a atmosfera. Este processo é especialmente intenso nas raízes; devido a ele, a microflora rizosférica utiliza o etanol liberado com muita rapidez como uma fonte de carbono. O acúmulo tóxico de etanol ao redor das raízes geralmente não é observado.

De acordo com Kramer (1951), a saturação do solo causa injúrias e até a morte de muitas espécies vegetais. Se o solo tiver maior quantidade de microorganismos, estes 
competem pelo oxigênio do ar do solo. As raízes do vegetal sofrem deficiência de oxigênio e as partes aéreas não produzem carbohidratos; as folhas morrem devido a absorção de substâncias tóxicas produzidas no ambiente anaeróbico do solo.

As relações entre produtividade das culturas e a umidade do solo são muito complexas e ainda não são bem entendidas, constituindo-se uma limitação para obtenção de um bom critério de drenagem (Bouwer, 1974).

Segundo Schilfgaarde \& Williamson (1965), em pesquisas desenvolvidas em casas de vegetação sobre a sensibilidade das plantas ao alagamento, verifica-se que as medidas necessárias para o estabelecimento de um critério útil para projetos de drenagem, constituem as informações sobre a variação da concentração de oxigênio no solo e sobre o movimento de água na zona radicular.

Uma curta deficiência de oxigênio pode causar aumento da resistência ao movimento da água através das raízes, redução da respiração radicular, redução da absorção de nutrientes e formação de produtos tóxicos. O prolongamento de uma aeração deficiente resulta na morte das células e consequentemente das raízes ( Williamson \& Kriz, 1970).

Segundo Cruciani (1987), a tolerância das culturas à deficiência de aeração, devido ao excesso de água, é muito variável, dependendo da duração do excesso, do estádio de desenvolvimento e da espécie vegetal. Os efeitos do excesso de água causam maior prejuízo quando ocorrem em um período crítico do desenvolvimento da planta (Rojas, 1984). Assim, por exemplo, no milho, o excesso de água, no primeiro período de crescimento, pode produzir clorose e retardar ou impedir o crescimento.

Existem contradições entre dados sobre limitações em relação ao crescimento de raízes ocasionados pelos níveis de oxigênio e dióxido de carbono no solo. Kramer (1969) aponta essa divergência e ressalta que as pesquisas foram desenvolvidas com diferentes espécies vegetais, em diversos estádios de crescimento, condições edafoclimáticas variadas e também utilizando diferentes metodologias experimentais. Em geral, as respostas das culturas aos coeficientes de difusão de oxigênio a índices inferiores a 20 . $10^{-8} \mathrm{~g} \mathrm{~cm}^{-2} \mathrm{~min}^{-1}$ são negativas e valores superiores a $40.10^{-8} \mathrm{~g} \mathrm{~cm}^{-2} \mathrm{~min}^{-1}$ são suficientemente altos para um bom crescimento da cultura. Por outro lado Williamson (1964) 
afirma ter obtido bons rendimentos em diversas culturas com coeficientes de difusão de oxigênio de $15 \cdot 10^{-8} \mathrm{~g} \mathrm{~cm}^{-2} \mathrm{~min}^{-1}$.

Segundo Baver et al. (1972), os efeitos da deficiência de aeração podem ser confundidos com a ocorrência de impedimentos mecânicos no solo.

Costa (1994) considera que a falta de aeração constitui um dos principais fatores causadores de enfermidades das plantas. Segundo ele, algumas evidências indicam que os efeitos nocivos são também produzidos pela atividade microbiológica em condições anaeróbicas. A magnitude das injúrias nas culturas varia conforme a espécie vegetal, tempo da inundação, a fase de crescimento, além da temperatura prevalecente na época da inundação.

\subsection{Objetivos e critérios da drenagem agrícola}

Segundo Cruciani (1987), a finalidade básica da drenagem artificial do solo é a remoção do excesso da água da superfície e/ou o rebaixamento do nível freático com o propósito de adequar o meio ao desenvolvimento normal dos cultivos.

Esta concepção é apropriada para regiões úmidas, onde se deve eliminar a água proveniente do escoamento superficial e realizar o controle da posição do lençol freático em relação à superfície do solo. No caso de regiões áridas e semi-áridas o propósito é o de controlar a salinidade do solo, mantendo-a a níveis que sejam toleráveis pelos cultivos. A intenção final da drenagem agrícola é a de manter as propriedades físicas e químicas do solo para propiciar um ambiente favorável ao desenvolvimento das culturas (Williamsom, 1970).

Para projetar um sistema de drenagem deve-se ter em conta a origem do encharcamento, as condições geológicas e topográficas do solo, as necessidades das plantas e as características especiais do agroecossistema. (Schwab et al., 1977). Uma das razões de maior importância pela qual os sistemas de drenagem muitas vezes não são utilizados, principalmente em solos rasos e de permeabilidade reduzida, é o custo de implantação que pode tornar-se elevado (Carter et al., 1984).

Os critérios de drenagem podem ser estabelecidos para condições de regime 
permanente ou não permanente. No primeiro caso é preciso se definir a profundidade ideal em que o lençol freático ficará estabilizado e para qual magnitude de recarga hidrológica. Este critério é geralmente utilizado em regiões de clima temperado onde a recarga se dá devido ao degelo da neve precipitada durante o inverno ou em situações onde as chuvas sejam bem distribuídas e de baixa intensidade. No segundo caso, os critérios de drenagem se aplicam a problemas de lençóis freáticos originados da percolação proveniente de precipitações intensas ou de irrigações e envolvem dois parâmetros básicos, além da magnitude da recarga, que são a profundidade de rebaixamento do lençol freático e o tempo que o lençol freático gasta para atingir a profundidade pré-estabelecida. Essa velocidade de descida do lençol freático vai depender das características hidrodinâmicas do solo e do sistema de drenagem implantado (Ferreira, 1987).

Segundo Pizarro (1978), para se determinar o espaçamento ótimo dos drenos de uma obra de drenagem, deve-se optar pelo critério econômico que dá uma maior relação custo/benefício e não pelo critério técnico-fisiológico, que geralmente objetiva evitar qualquer decréscimo na produção da cultura.

Uma vez que os sistemas de drenagem sejam planejados e executados adequadamente (com o conhecimento da variável sensibilidade da planta ao encharcamento), pode-se obter um grau de controle do lençol freático suficiente para a habilitação de solos que antes permaneciam inundados o ano todo, permitindo a prática da agricultura ou pecuária, além de assegurar a produção nos terrenos alagados parcialmente, com uma melhor relação beneficio/custo (Silva, 1982).

\subsection{Resposta das culturas à profundidade do lençol freático}

Cruciani (1987) considera que a profundidade do lençol freático não tem efeito direto no crescimento do vegetal, e influi indiretamente apenas na determinação das condições de umidade do perfil de solo. O lençol freático torna-se importante pela facilidade da medição de sua profundidade. Como essas medidas são muito mais fáceis de serem realizadas do que as determinações de macroporosidade, taxa de difusão de oxigênio, potencial de oxi-redução, entre outras, numerosos experimentos de campo e com 
lisímetros têm sido conduzidos para determinar a resposta da cultura à profundidade do lençol. Entretanto os resultados obtidos ainda distam muito de ser definitivos devido à complexidade fisiológica do fenômeno e a intevenção de muitos fatores, tais como a necessidade particular de aeração das diversas culturas, condições climáticas, tipo de solo, método de irrigação, risco de salinização, trânsito de máquinas agrícolas e aspectos econômicos (Pizarro, 1978; Beltrán, 1986).

As espécies vegetais e algumas vezes os vários cultivares de uma mesma espécie respondem diferentemente à profundidade do lençol freático, conforme o estádio de desenvolvimento. A distribuição das raízes das várias espécies afeta a resposta às condições de aeração do solo. Espécies de sistema radicular raso e fibroso são mais eficientes na absorção de oxigênio, em condições de aeração pobre, do que plantas de sistema radicular profundo. Diferenças genéticas inatas, propiciam respostas diferentes das espécies e cultivares à composição gasosa da atmosfera do solo. Entretanto, o efeito nocivo do excesso de água no solo está mais correlacionado à ausência de oxigênio do que ao excesso de gás carbônico (Williamson \& Kriz, 1970). Segundo esses autores, a idade fisiológica da cultura promove alterações no grau de hidratação dos tecidos e da taxa necessária de oxigênio para a respiração celular, acarretando amplas variações na resposta à deficiência de aeração. Pizzaro (1978) observa que o próprio aumento da profundidade das raízes com o desenvolvimento da cultura altera a profundidade ótima do lençol freático do ponto de vista técnico.

O efeito nocivo da deficiência de aeração é tanto pior quanto maior for a temperatura ambiente, pois as raízes e os microrganismos do solo passam a requerer mais oxigênio, cuja concentração diminui mais rapidamente. Paralelamente, altas temperaturas promovem aumento da transpiração e das necessidades de absorção de água, agravando o desequilíbrio, pois em condições de falta de oxigênio a atividade de absorção das raízes é reduzida (Williamson e Kriz, 1970). Ainda segundo esses autores, no que se refere à profundidade adequada do lençol freático, experimentos de campo podem apresentar resultados conflitantes quando conduzidos em anos secos ou úmidos, resultando em profundidades menores ou maiores, respectivamente, devido ao efeito sobre a umidade do perfil. 
Há duas formas de se avaliar a posição ideal do lençol freático: com ausência ou presença de irrigação. No primeiro caso, mais indicado para zonas úmidas, existe a possibilidade de se utilizar a água do lençol para sub-irrigação. Portanto, devem existir duas profundidades limites: uma superior, para que não haja deficiência de aeração e uma inferior, para que não haja deficiência de água (Williamson \& Kriz, 1970; Pizarro, 1978). A profundidade ideal seria aquela que propiciasse uma condição de fluxo permanente, igualando a taxa de ascensão capilar à evapotranspiração da cultura (Millar, 1978). No segundo caso, a utilização de irrigação superficial faz com que a condição de lençol mais baixo forneça a melhor produção (Williamson \& Kriz, 1970).

No que diz respeito ao efeito do tipo de solo, para um dado potencial matricial, solos de textura mais fina se mantêm num teor de umidade mais elevado, apresentando uma franja capilar mais extensa do que os solos de textura mais grossa. Consequentemente, em geral, espera-se que os solos mais argilosos requeiram lençol a uma profundidade superior do que os arenosos (Millar, 1978; Canell e Jackson, 1981).

Quanto à questão do risco de salinização em regiões semiáridas, recomenda-se que o lençol freático se mantenha suficientemente profundo para permitir a lixiviação de sais e minimizar o fluxo capilar à zona radicular (Beltran, 1986). A FAO (1980) recomenda que o lençol seja mantido a uma profundidade mínima de 1,4 m em solos de textura grossa e fina e de 1,7 m em solos de textura média. Cruciani (1987) sugere que, quando possível, adote-se um valor mínimo de 1,8 m.

A posição do lençol freático influencia também em aspectos da exploração agrícola tais como a possibilidade de trânsito de máquinas para o preparo do solo, o cultivo e a colheita. A mobilidade das máquinas exige geralmente que a camada do solo trabalhada esteja com umidade inferior à capacidade de campo. Para satisfazer a esse objetivo Beltrán (1986) sugere valores de profundidade de 1,0 a 1,5m.

Segundo Pizarro (1978), no caso da drenagem em regiões semi-áridas, a instalação de um sistema que assegure profundidade ótima do lençol, ou seja, que não ocasione diminuição na produção, é muitas vezes antieconômica. Assim, geralmente prefere-se que as culturas não alcancem a produtividade máxima para se conseguir baratear as obras. A profundidade ideal do lençol para fins de projeto, portanto, seria aquela que pro- 
piciasse uma maior relação benefício-custo. Entretanto, segundo este mesmo autor, a dificuldade de se adotar este critério reside no fato de não se dispor de dados que permitam quantificar com segurança a diminuição da produção das diversas culturas ocasionada pela presença do lençol a diferentes profundidades. Além disso, o custo do projeto, das máquinas e dos materiais, assim como o custo de produção da cultura e seu preço de venda variam bastante de uma região para outra, sendo de difícil previsão. Por outro lado, segundo Kandil \& Williardson (1992), estudos que procuram estabelecer correlações entre níveis de estresse por excesso de água no solo com dados de produtividade podem ser utilizados para determinar o espaçamento de drenos mais econômico permitindo obter-se um sistema de drenagem que propicie o maior retorno ao longo de sua vida útil.

Na literatura encontram-se diversos trabalhos que procuraram estabelecer valores indicativos da profundidade ideal do lençol freático, quando mantido estático, valores esses que visam auxiliar na definição de critérios de drenagem para a condição de regime permanente.

Trabalhos desenvolvidos por Harris et al. (1962) e van Hoorn (1958) mostraram que para a maioria das culturas, quanto menor foi a profundidade do lençol freático no solo, menor foi a produção obtida. Por outro lado, lençóis freáticos muito profundos, em condições de ausência de irrigação, tornaram-se prejudiciais pela falta de umidade na zona radicular.

van’t Woudt \& Hagan (1967) apresentaram uma tabela de rendimento relativo de diversas culturas para diferentes profundidades do lençol freático. Os valores que permitiram maiores produtividades variam de 60 a $150 \mathrm{~cm}$.

Williamson e Kriz (1970), revisando vários trabalhos, chegaram a uma tabela semelhante para 23 culturas, com observações quanto ao efeito da textura do solo e ao fato de haver ou não irrigação superficial. Profundidades que propiciaram 100\% de rendimento variaram de 15 a $150 \mathrm{~cm}$.

Pizarro (1978) fornece os seguintes valores indicativos para a profundidade do lençol: para pastos, de 40 a $80 \mathrm{~cm}$, dependendo da textura do solo; para culturas extensivas, de 60 a 150 cm, em função de cada espécie; para hortaliças, valores variando de 40 
a $80 \mathrm{~cm}$, dependendo da cultura e para árvores, mais de $1,5 \mathrm{~m}$ para fruteiras em geral e de 2,5 a 3 m para árvores de frutos secos.

Segundo van de Goor (1980), níveis freáticos muito elevados podem exercer uma grande influência na produção das culturas, dependendo do estádio de desenvolvimento, mesmo que estes estresses sejam de curta duração.

A FAO (1980) sugere valores de profundidade do lençol para cultivos herbáceos, hortaliças e fruteiras, segundo a textura e o regime de fluxo. Para fluxo permanente os valores oscilam de 1,0 a $1,6 \mathrm{~m}$.

Beltran (1986), analisando o trabalho de Williamson \& Kriz (1970), concluiu que cultivos herbáceos admitem uma profundidade mínima de lençol de 80 a $90 \mathrm{~cm}$ em solos argilossos e de 60 a 75 cm em solos franco-arenosos; para plantas hortícolas, em solo franco, de 50 a $60 \mathrm{~cm}$.

Lima et al. (1986), estudando o efeito da profundidade do lençol freático como fonte de suprimento de água para a cultura do feijoeiro, não observaram diferenças significativas da produção para profundidades do lençol entre 55 e 84 cm. Entretanto, quando o lençol foi mantido à profundidade superior a $84 \mathrm{~cm}$, houve decréscimo no desenvolvimento das plantas e queda acentuada na produção.

Segundo Cruciani (1987), alguns valores recomendados por vários pesquisadores indicam uma profundidade de lençol de 60 a $90 \mathrm{~cm}$ para solos arenosos e de 100 a 150 cm para solos argolosos. Este autor ressalta que, dentro desses limites, as variações possíveis dependem da cultura, do solo e das condições climáticas locais.

Em estudos de níveis do lençol freático desenvolvido por Farias (1996) no perímetro irrigado de Sao Gonçalo, PB, encontraram-se profundidades médias entre 0,40 e 3,68 m, que afetariam o sistema radicular de várias culturas, seja pelo excesso ou falta de umidade. 


\subsection{Dinâmica do lençol freático e tolerância das culturas}

Segundo a literatura, a maioria das pesquisas sobre a sensibilidade das plantas a inundações do solo foram desenvolvidas com níveis constantes de lençol freático. Esta condição geralmente não ocorre nas regiões úmidas com chuvas intensas e em áreas irrigadas, onde a recarga supera a descarga, observando-se uma flutuação do nível do lençol freático, constituindo-se em um fluxo variável (Pizarro, 1978; Luthin, 1973).

Do ponto de vista do dimensionamento de um sistema de drenagem, os efeitos de lençóis flutuantes no crescimento das culturas são muito mais importantes do que os estáticos, já que na prática as recargas geralmente são intensas (Cannel e Jackson, 1981). É necessário, portanto, definir critérios de drenagem em termos dinâmicos, ou seja, estabelecer o número de dias após a recarga em que o lençol deve ser rebaixado e para qual profundidade (Pizarro, 1978).

Tovey (1964), trabalhando com alfafa em lisímetros, com flutuações de lençol freático com elevações $30 \mathrm{~cm}$ até a superfície do solo em tempos de 1 a 11 dias, observou que nos tratamentos de a partir de 9 dias a produção caiu a zero e nos tratamentos de 1, 2 e 3 dias a produção superou as testemunhas. Concluiu que o excesso de água na zona radicular, provocado pelo lençol freático elevado, deve ser removido para evitar deterioração progressiva das raízes após o terceiro dia da ocorrência da inundação.

As hortaliças só resistem ao excesso d’água por poucas horas, segundo Millar (1978). Os cereais e outras culturas de ciclo curto podem resistir a um encharcamento de 24 horas; as pastagens permitem uma condição de inundação de três ou mais dias, podendo chegar a 20, conforme a espécie. Este autor apresenta ainda uma tabela que estima a percentagem de danos produzidos por inundações de 3, 7, 11 e 15 dias para algumas culturas.

Pizarro (1978) propõe um critério de drenagem para períodos chuvosos do ano no qual é permitido a elevação do lençol freático até uma certa profundidade com uma freqüência de “N” vezes por ano. Em geral usa-se o valor $\mathrm{N}$ igual a 5 vezes por ano. 
Este autor apresenta como orientação a Tabela 1, na qual encontram-se os valores de profundidade do lençol freático desejável, para três classes de cultura, de acordo com o número de dias depois da chuva.

Tabela 1. Profundidade critica do lençol freático (m) para condições de chuva, segundo Pizarro (1978)

\begin{tabular}{cccc}
\hline Dias depois da chuva & & & \\
& Classe A & Classe B & Classe C \\
\hline 0 & 0,30 & 0,50 & 0,90 \\
2 & 0,50 & 0,80 & 1,10 \\
3 & 0,70 & 1,00 & 1,30 \\
\hline
\end{tabular}

Classe A: pastos e grande parte das hortaliças

Classe B: maior parte das culturas extensivas.

Classe C: frutas.

A FAO (1980) não fornece informações sobre a tolerância das culturas ao lençol freático, quando o mesmo satura temporariamente a zona radicular, declarando não dispor de experiência suficiente para tal. Sugere, entretanto, valores de profundidades mínimas permissíveis para lençol em fluxo transiente. Estes valores variam com o tipo de cultura e a textura do solo, na faixa de 0,9 a $1,4 \mathrm{~m}$.

Segundo Beltrán (1986), para plantas herbáceas cultivadas na Espanha, em solos argilosos e com irrigação, tolera-se que o lençol freático permaneça a menos de $25 \mathrm{~cm}$ de profundidade de 1 a 2 dias, um período similar de 25 a $50 \mathrm{~cm}$, devendo atingir de 45 a 75 cm em 4 a 5 dias após a recarga.

Alguns experimentos já foram realizados na ESALQ/USP em Piracicaba por Cruciani (1981b e 1985) e Cruciani \& Minami (1982 e 1984), visando determinar a susceptibilidade de algumas culturas a inundações temporárias. Os resultados obtidos recomendam que o tempo de drenagem da zona radicular seja inferior a 3 dias para as culturas do trigo e do milho e inferior a 2 dias para a cultura do pimentão. A aveia não tolera 
nem um dia de saturação aos 90 dias após a semeadura e, em outros períodos, 2 dias já é considerado excessivo.

A sensibilidade das culturas é também bastante dependente do estágio fenológico em que a inundação ocorre. Experimentos realizados com as culturas do trigo, feijão, pimentão e milho revelaram que a floração é o estádio em que o encharcamento causa maior redução de produtividade e que no estádio final do ciclo o efeito adverso do encharcamento diminui (Cruciani, 1981b; Silva, 1982; Cruciani \& Minami, 1982; Cruciani, 1985). Para culturas cujo ciclo comercial não chega a atingir o florescimento, como a cultura da alface, existem poucos relatos na literatura a respeito do estádio mais sensível. Costa et al. (2003), imprimindo estresses por elevação do lençol freático em três fases do ciclo de uma cultura de beterraba, observaram maiores reduções na produtividade das plantas submetidas ao encharcamento ocorrido na terceira fase.

\subsection{Relação entre a produtividade das culturas e o índice diário de estresse por excesso de água no solo}

O efeito da variação do nível freático na produção de algumas culturas foi estudado por Sieben em 1964 (Bouwer, 1974). Sieben introduziu o conceito de SEWp ( somatório dos excedentes de água acima da profundidade p), para determinar os efeitos da flutuação do lençol freático sobre culturas de cereais durante a estação de inverno. $\mathrm{O}$ valor de SEWp pode ser obtido a partir da expressão 1 .

$\mathrm{SEWp}=\sum_{\mathrm{j}=1}^{\mathrm{m}}(\mathrm{P}-\mathrm{Xj})$

em que:

SEWp - somatório dos excedentes de água acima da profundidade “p”, cm dia;

$\mathrm{P}$ - profundidade crítica do lençol freático, cm;

$\mathrm{Xj}$ - profundidade média do lençol freático durante o dia j, cm;

m - número de dias em que o lençol freático permanece acima de p durante o ciclo da cultura. 
Segundo Wesseling (1974), Sieben considerou como nível crítico do lençol freático a profundidade de $30 \mathrm{~cm}$ e passou a utilizar a sigla $\mathrm{SEW}_{30}$. Além de fornecer uma indicação sobre o tempo de permanência do lençol freático a uma profundidade menor que $30 \mathrm{~cm}$, o índice $\mathrm{SEW}_{30}$ permite também uma avaliação da qualidade da drenagem (Obreza et al., 1993). Sieben observou que a produção de algumas culturas começa a decrescer quando os valores de $\mathrm{SEW}_{30}$ encontram-se entre 100 a $200 \mathrm{~cm}$ dia.

Carter et al. (1988) constataram que a ocorrência de valores de $\mathrm{SEW}_{30}$ acima de $100 \mathrm{~cm}$ dia durante a fase de crescimento do milho e durante o período de repouso vegetativo da cana-de-açúcar pode ser considerada uma indicação de problemas de aeração do solo e, consequentemente, de necessidade de drenagem.

Kanwar et al. (1988) afirmam que o incremento nos valores do $\mathrm{SEW}_{30}$ provoca a diminuição na população de plantas e na produção de matéria seca do milho. Os autores observaram ainda que o modelo de regressão linear foi adequado para descrever a produtividade em função do $\mathrm{SEW}_{30}$.

Uma limitação do uso do $\mathrm{SEW}_{30}$ no estudo da resposta das culturas à flutuação do lençol freático é o fato de se assumir que o estresse imposto à cultura por essa flutuação pode ser aditivo. Isso implica que valores iguais de $\mathrm{SEW}_{30}$ obtidos a partir de diferentes níveis de drenagem vão produzir níveis de estresse iguais na cultura. Por exemplo, para culturas em um mesmo estádio de desenvolvimento, o método sugere que um lençol freático mantido a $5 \mathrm{~cm}$ de profundidade por um dia $\left(\mathrm{SEW}_{30}=25 \mathrm{~cm}\right.$ dia) tem o mesmo efeito que um lençol mantido a $25 \mathrm{~cm}$ de profundidade durante cinco dias $\left(\mathrm{SEW}_{30}=25 \mathrm{~cm}\right.$ dia), o que pode não ser verdadeiro (Patwardhan et al., 1988). Outra limitação na correlação direta do $\mathrm{SEW}_{30}$ com a produtividade diz respeito ao fato do índice não considerar as diferentes respostas em função dos estádios de desenvolvimento da cultura.

Hiler (1969) apresentou alguns critérios para dimensionamento de sistemas de drenagem e propôs um método que incorpora as necessidades de drenagem das culturas às teorias de drenagem. Este método utiliza o conceito do Índice Diário de Estresse (IDS), introduzido por este autor, e tem sido, desde então, usado largamente por outros pesquisadores (Kanwar, 1988). 
O conceito do IDS possui significado quantitativo e permite determinar o grau de estresse imposto a uma cultura durante diferentes estádios de desenvolvimento. O IDS para um determinado estádio é determinado em função do fator de estresse diário e do fator de susceptibilidade da cultura. O fator de estresse diário (SD) é a medida do grau e duração do estresse por excesso de água, enquanto o fator de susceptibilidade da cultura (SC) caracteriza a sensibilidade da cultura a danos por excesso de água no solo nos seus diferentes estádios de desenvolvimento. Assim, o IDS para um dado período é a soma dos produtos do fator de susceptibilidade da cultura pelo fator de estresse diário, conforme aprsentado na equação 2.

$$
\operatorname{IDS}=\sum_{i=1}^{\mathrm{n}}\left(\mathrm{SC}_{\mathrm{i}} \mathrm{SD}_{\mathrm{i}}\right)
$$

em que:

IDS - índice diário de estresse, cm dia;

n - número de estádios de crescimento da cultura;

$\mathrm{SC}_{\mathrm{i}}$ - fator de susceptibilidade da cultura no estádio i, adimensional;

$\mathrm{SD}_{\mathrm{i}}$ - fator de estresse diário da cultura no estádio i, cm dia.

O fator de susceptibilidade da cultura é definido por:

$$
\mathrm{SC}=\frac{\mathrm{Yo}-\mathrm{Yi}}{\mathrm{Yo}}
$$

em que:

Yo - produção da cultura sem estresse, $\mathrm{kg} \mathrm{ha}^{-1}$;

Yi - produção da cultura sob condições de estresse no estádio i, $\mathrm{kg} \mathrm{ha}^{-1}$.

O método mais comum de determinação do SC consiste em submeter a cultura a um nível específico de estresse ( em razão de condições de excesso de água no solo) em cada um dos estádios de desenvolvimento e comparar a produtividade com a de um 
tratamento testemunha que não sofreu estresse. Os valores de SC variam de zero, para o estádio no qual a cultura é insensível ao estresse, até valores próximos de um, para os estádios em que a cultura é mais sensível ao excesso de água no solo (Ahmad \& Kanwar, 1989). Estes autores comentam, entretanto que fatores não controlados (genótipo, tipo de solo, fertilidade do solo, temperatura, etc ) podem acarretar diferenças nos valores de SC determinados experimentalmente para uma mesma cultura.

Quanto ao fator de estresse diário, Hardjoamidjojo et al. (1982) e Skaggs (1990) sugerem que o mesmo pode ser estimado pelo índice $\mathrm{SEW}_{30}$, isto é, para cada estádio de desenvolvimento considera-se $\mathrm{SD}=\mathrm{SEW}_{30}$.

Kanwar et al. (1988) e Mukhtar et al. (1990) obtiveram relações entre a produtividade relativa para a cultura do milho e o IDS; observaram um decréscimo linear da produção à medida que o valor de IDS aumentava.

Gayle et al. (1987), estudando a relação entre o excesso de água no solo e a produção da cultura da cana de açúcar, obervaram, ao quantificar o SD pelo valor do $\mathrm{SEW}_{45}$, uma relação linear decrescente entre a produtividade relativa e o IDS.

Vildoso (1995), trabalhando com a cultura da cenoura em Viçosa - MG, observou que o modelo de regressão que apresentou melhor ajuste aos dados de peso médio das raízes, comprimento médio das raízes, comprimento da maior folha e produção total em função do IDS foi o quadrático. Já para produção total de matéria seca e produção comercial relativa e melhor ajuste foi obtido com o modelo linear.

Segundo Hiler \& Clark (1971), o conceito do IDS é aplicável não só para caracterizar as necessidades de drenagem das culturas, mas também as necessidades de irrigação, servindo, portanto, para avaliar tanto os efeitos da deficiência quanto do excesso de água no solo.

Com o avanço das técnicas de programação ocorrido nas últimas décadas, surgiram vários modelos para avaliação do desempenho de sistemas de drenagem como o DRAINMOD (Skaggs, 1981), o SIMDRENO (Duarte et al., 1998) e o SISDRENA (Miranda et al., 1998), entre outros. Estes modelos simulam a flutuação do lençol freático para diferentes combinações entre espaçamento e profundidade de drenos, para uma série de dados meteorológicos de vários anos; fazendo uso de relações entre a 
produtividade da cultura e o IDS, estimam a produção obtida para cada ano, o que permite identificar qual dos sistemas testados apresenta-se como o mais econômico. 


\section{MATERIAL E MÉTODOS}

É importante destacar que a metodologia empregada na condução do experimento é bem simples e baseia-se na hipótese mantida por vários autores de que é possível se avaliar a sensibilidade de uma cultura ao encharcamento, a partir da condição de alagamento total, com diferentes velocidades de rebaixamento do lençol freático, em diferentes estádios de desenvolvimento do vegetal.

\subsection{Local e estrutura das parcelas experimentais}

O trabalho foi desenvolvido a céu aberto na área experimental do Setor de Hidráulica do Departamento de Engenharia Rural da Escola Superior de Agricultura "Luiz de Queiroz”, da Universidade de Sao Paulo, em Piracicaba - SP, com a cultura da batata, no período de julho a novembro 2001, e com a cultura da alface, no período de dezembro 2001 a janeiro 2002. As coordenadas geográficas locais são 20³8’30” de latitude sul, e $47^{\circ} 38^{\prime} 00^{\prime}$ de longitude oeste, a $580 \mathrm{~m}$ de altitude.

Foram utilizados como recipientes 52 vasos de cimento para a cultura da batata e 39 vasos de cimento para a cultura da alface. Cada recipiente cilíndrico possuía a capacidade de 235 litros e as seguintes dimensões: 1,20 m de profundidade e 0,50 m de diâmetro interior, apresentando uma superfície aproximada de 0,20 $\mathrm{m}^{2}$ cada um. Os recipientes foram posicionados em linha reta, e cada um se constituiu em uma parcela experimental (Figura 1). Os recipientes foram preenchidos com material de solo da série "Sertãozinho" (Latossolo Vermelho Amarelo), de textura franco-arenosa ( $71 \%$ de areia, $7 \%$ de silte e $22 \%$ de argila), homogeneizado e retirado da camada de 0 a $0,50 \mathrm{~m}$ de profundidade de seu perfil natural. 


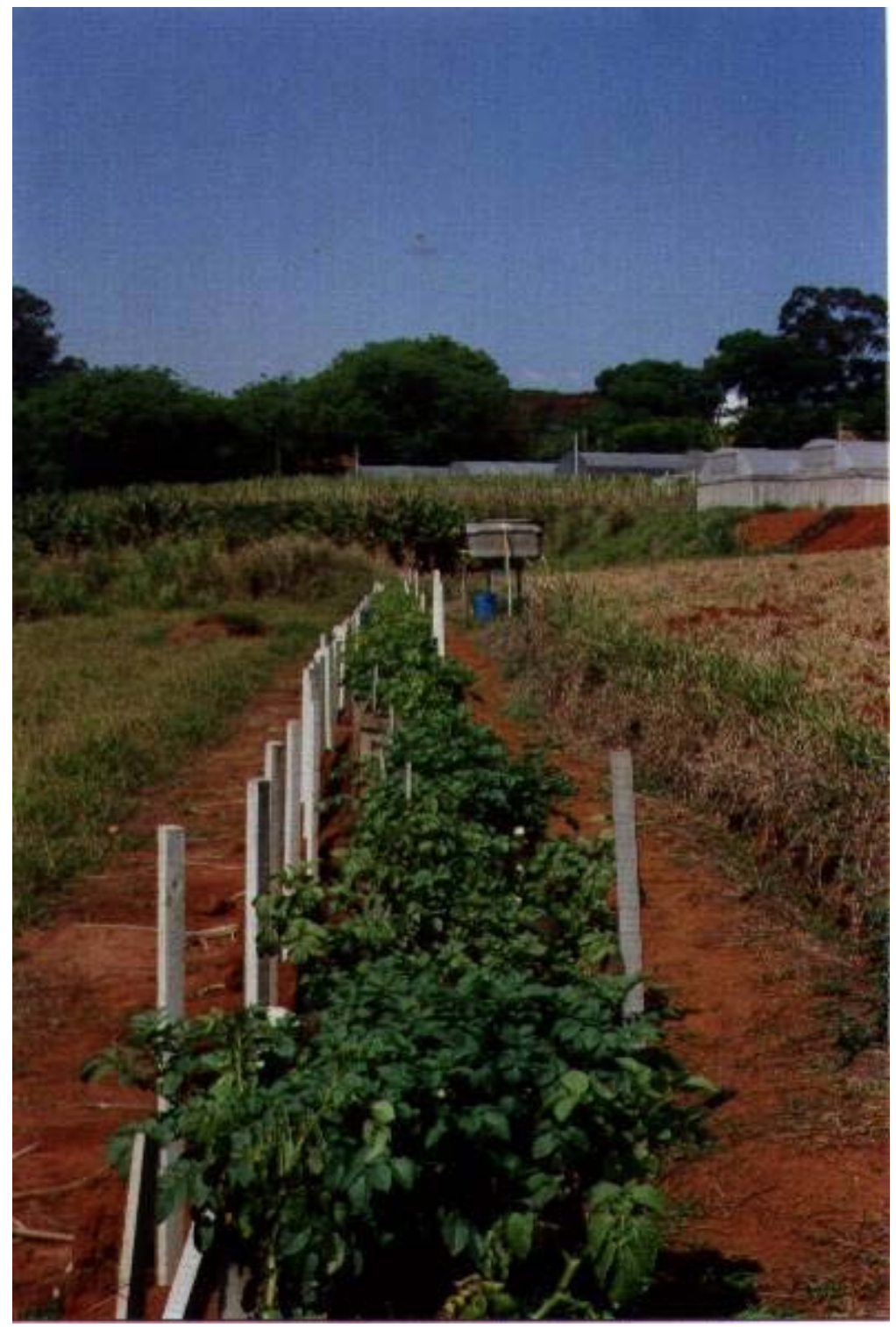

Figura 1- Vista panorâmica da área experimental durante o ciclo da cultura da batata

\subsection{Sistema de alimentação e drenagem dos recipientes}

O sistema de fornecimento de água aos recipientes, para seu alagamento, compreendia de dois reservatórios elevados de cimento-amianto com capacidade de 1000 litros cada, providos de chaves-bóia e instalados sobre uma estrutura de madeira com 2,5 
m de comprimento, 1,6 m de largura, que mantinha o fundo dos reservatórios a 1,6 m do topo dos vasos de cimento.

Partindo desses reservatórios, o abastecimento de água aos recipientes de cimento realizou-se por meio de uma rede subterrânea de tubos de PVC e de polietileno, ambos com 19 mm de diâmetro, localizados paralelamente à linha da bateria de recipientes. Estes encanamentos afloravam na frente de cada recipiente, a uma distância média de 1 metro. Neste ponto havia uma derivação onde acoplava-se uma mangueira de plástico cristal de 12,5 mm conectada a um registro de PVC. Após o registro havia outra mangueira, também de plástico cristal e com 12,5 mm de diâmetro, para a alimentação de um reservatório de PVC. Este reservatório possuía forma cilíndrica com dimensões de 0,30 m de diâmetro e 0,30 m de altura, sendo provido de chave-bóia. A finalidade deste reservatório era o controle e a manutenção individual do nível do lençol freático no interior de cada recipiente, nos quais foram aplicados os diferentes tratamentos.

Próximo a base de cada recipiente localizava-se um orifício para admissão de água proveniente do reservatório de PVC. Neste orifício foi inserido um tubo de PVC de 12,5 mm de diâmetro, com um comprimento de $60 \mathrm{~cm}$, e furos de $10 \mathrm{~mm}$ de diâmetro em seu perímetro, espaçados a $10 \mathrm{~cm}$ entre si. Esses tubos serviram também para realizar a drenagem dos recipientes.

O sistema de drenagem previsto no recipiente consistia de uma camada de brita número 1 com $4 \mathrm{~cm}$ de espessura, separada do solo por uma manta geotêxtil não tecida (Bidim OP 30). O sistema de drenagem permitia realizar a rápida evacuação da água ao se desligar a alimentação dos recipientes após a aplicação dos tratamentos e também depois das precipitações intensas. A Figura 2 representa esquematicamente um recipiente-parcela.

\subsection{Tratamentos para ambas as culturas}

O experimento foi desenvolvido de forma semelhante para as culturas de batata (Solanum tuberosum, L) e alface (Lactuca sativa, L). 


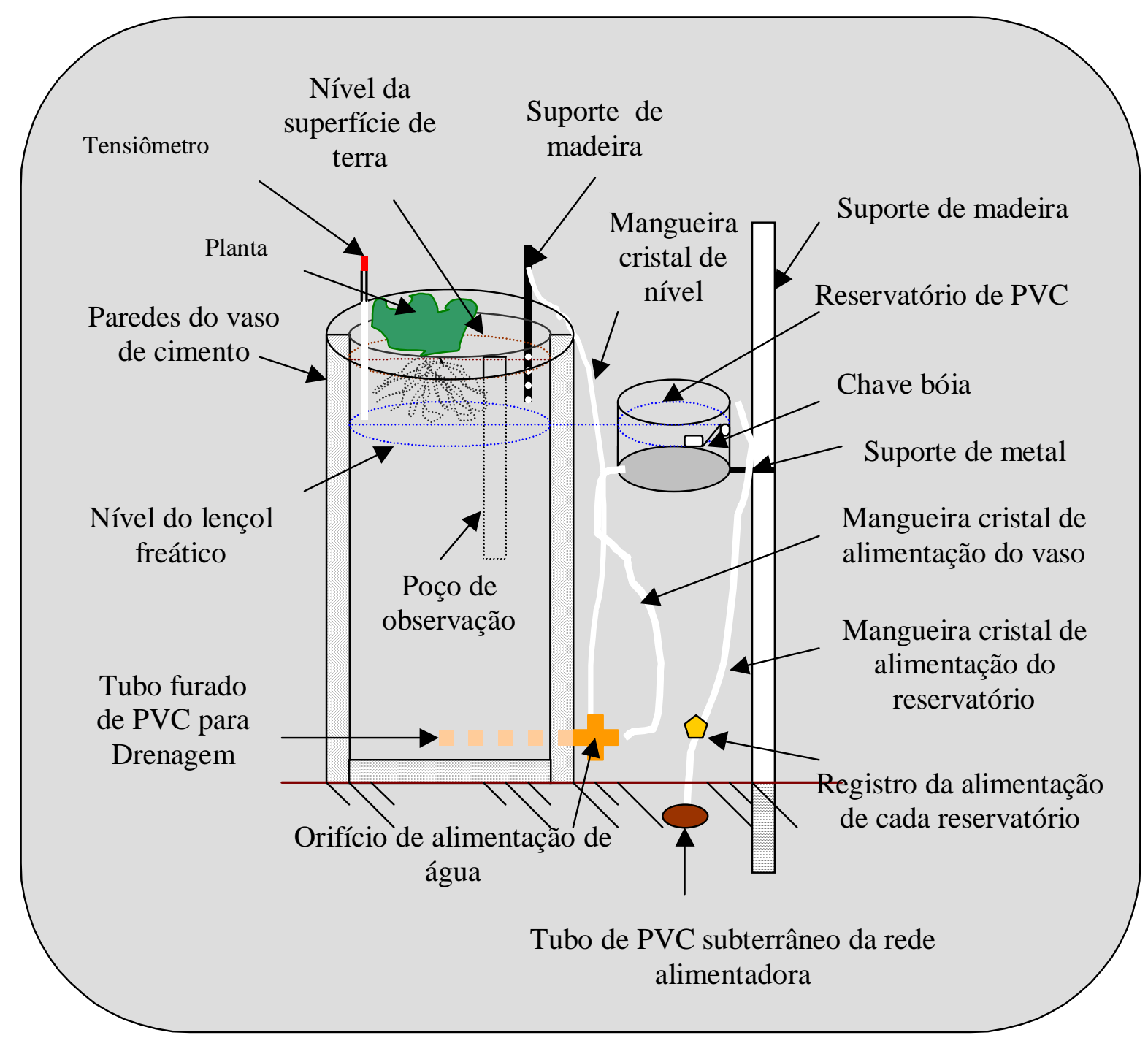

Figura 2 - Esquema dos elementos componentes do sistema de inundação de um recipiente

Os tratamentos constaram de diferentes velocidades de rebaixamento do lençol freático, quais sejam, 24, 48, 72 e 96 horas, desde um alagamento do recipiente, com uma altura inicial média tangente à superfície do solo (Figura 3), até atingir-se a profundidade de 0,30 m. Estes encharcamentos foram promovidos em três estádios dos ciclos fenológicos das culturas, havendo também um tratamento testemunha sem inun- 
dação, o que totalizou 13 tratamentos em um delineamento experimental inteiramente casualizado, em esquema fatorial $(4 \times 3+1)$. Para a cultura da batata foram utilizadas 4 repetições, totalizando 52 parcelas, enquanto que para a cultura da alface foram utilizadas apenas 3 repetições, totalizando 39 parcelas, devido ao fato de ter havido morte de algumas plantas.

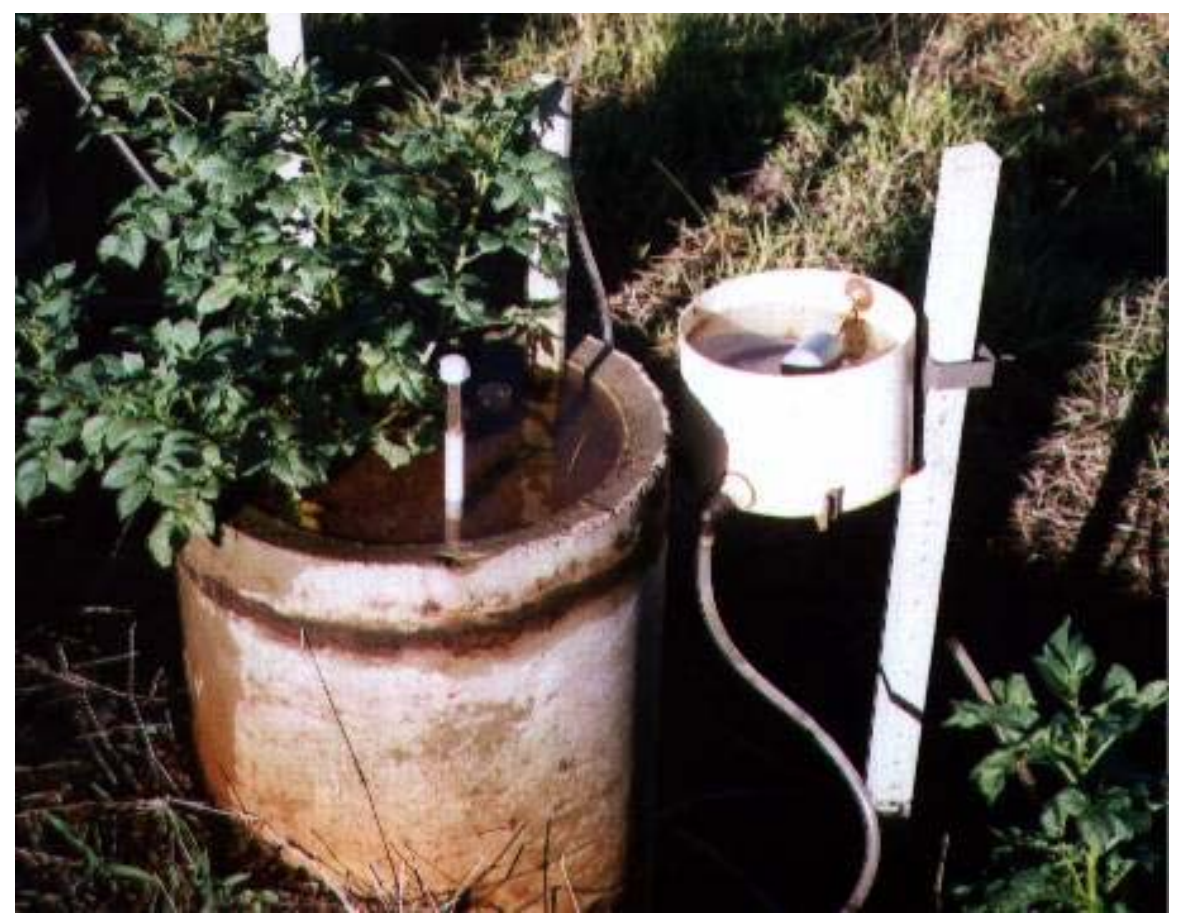

Figura 3- Inundação de um recipiente cultivado com batata

\subsection{Cálculo das profundidades intermediárias do lençol freático}

Para o cálculo das profundidades intermediárias do lençol freático, relativas aos diferentes tratamentos durante os rebaixamentos, foi utilizada a fórmula de Boussinesq \& Glover (Schilfgaarde, 1974) representada pela equação 4:

$$
S^{2}=\frac{9 \cdot K \cdot t}{2 \cdot \alpha} \cdot\left(\frac{h_{0} \cdot h_{t}}{h_{0}-h_{t}}\right)
$$


em que:

$\mathrm{S}=$ espaçamentos entre drenos, $\mathrm{m}$;

$\mathrm{K}=$ condutividade hidráulica do solo saturado, $\mathrm{m} \mathrm{d}^{-1}$;

$\mathrm{t}=$ tempo de rebaixamento, $\mathrm{d}$;

$\alpha=$ porosidade drenável, decimal ;

$\mathrm{h}_{0}=$ distância inicial do lençol em relação ao plano que passa na linha dos drenos, m;

$\mathrm{h}_{\mathrm{t}}=$ distância final do lençol freático em relação ao plano que passa na linha dos drenos, $\mathrm{m}$.

Desenvolvendo a equação 4, obtém-se:

$\frac{S^{2} \cdot 2 \cdot \alpha}{9 \cdot K}=\frac{t \cdot h_{0} \cdot h_{t}}{\left(h_{0}-h_{t}\right)}$

Introduzindo uma variável auxiliar W, tem-se:

$W=\frac{S^{2} \cdot 2 \cdot \alpha}{9 \cdot K}$

Substituindo-se (6) em (5), obtém-se a equação 7:

$W=\frac{t \cdot h_{0} \cdot h_{t}}{\left(h_{0}-h_{t}\right)}$

Explicitando-se o valor de ht na equação 7, tem-se a equação 8:

$$
h_{t}=\frac{W \cdot h_{0}}{\left(W+t \cdot h_{0}\right)}
$$

Considerando $\mathrm{h}_{0}=1 \mathrm{~m}$ (distância do centro do tubo de drenagem à superfície do solo) e $h_{t}=0,70 \mathrm{~m}$ (distância do centro do tubo de drenagem ao plano localizado a uma profundidade de $30 \mathrm{~cm}$ abaixo da superfície do solo), para t igual a 1, 2, 3 e 4 dias, ob- 
tém-se os valores de W igual a 2,33 , 4,67 , 7,00 e 9,33. A equação 8, aplicada com estes valores de W, foi utilizada para o cálculo das profundidades intermediárias do lençol freático, visando contabilizar o fato do rebaixamento do lençol não ser linear. Como resultado foram obtidas as profundidades apresentadas na Tabela 2.

Tabela 2. Profundidades do lençol freático (cm) em função do tempo, para as diferentes velocidades de rebaixamento

\begin{tabular}{|c|c|c|c|c|}
\hline \multirow{2}{*}{$\mathrm{T}$ (dias) } & $30 \mathrm{~cm} \mathrm{em}$ & $30 \mathrm{~cm} \mathrm{em}$ & 30 cm em & $30 \mathrm{~cm} \mathrm{em}$ \\
\hline & 1 dia $\left(V_{1}\right)$ & $2 \operatorname{dias}\left(V_{2}\right)$ & 3 dias $\left(V_{3}\right)$ & $4 \operatorname{dias}\left(V_{4}\right)$ \\
\hline 0,0 & 0,0 & 0,0 & 0,0 & 0,0 \\
\hline 0,5 & 17,7 & 9,7 & 6,7 & 5,1 \\
\hline 1,0 & 30,0 & 17,6 & 12,5 & 9,7 \\
\hline 1,5 & 39.2 & 24,3 & 17,6 & 13,9 \\
\hline 2,0 & 46.2 & 30,0 & 22,2 & 17,7 \\
\hline 2,5 & 51.8 & 34,9 & 26,3 & 21,1 \\
\hline 3,0 & 56.3 & 39,1 & 30,0 & 24,3 \\
\hline 3,5 & 60.0 & 42,8 & 33,3 & 27,3 \\
\hline 4,0 & 63.2 & 46,1 & 36,4 & 30,0 \\
\hline 4,5 & no fundo & no fundo & no fundo & no fundo \\
\hline 5,0 & no fundo & no fundo & no fundo & no fundo \\
\hline
\end{tabular}

\subsection{Controle do nível do lençol freático}

O nível do lençol freático nos recipientes correspondentes aos tratamentos foram monitorados mediante poços de observação escavados no material de solo e revestidos por tubos de PVC perfurados, de $50 \mathrm{~mm}$ de diâmetro e $90 \mathrm{~cm}$ de profundidade, separados do solo por manta geotêxtil não tecida (Bidim OP 30).

Para se executar a metodologia de rebaixamento do lençol freático, as profundi- 
dades foram determinadas por uma régua com flutuador, que era inserida nos poços de observação instalados nos recipientes (Figura 4) até atingir um nível estável em cada altura estabelecida para o rebaixamento. No desenvolvimento do trabalho constatou-se diferenças entre as medições realizadas pela régua com flutuador e aquelas feitas nas mangueiras de plástico cristal de nível de água, razão pela qual descartou-se esta última como instrumento de aferição da profundidade do lençol. Os rebaixamentos foram realizados a cada 12 horas, conforme apresentado na Tabela 2.

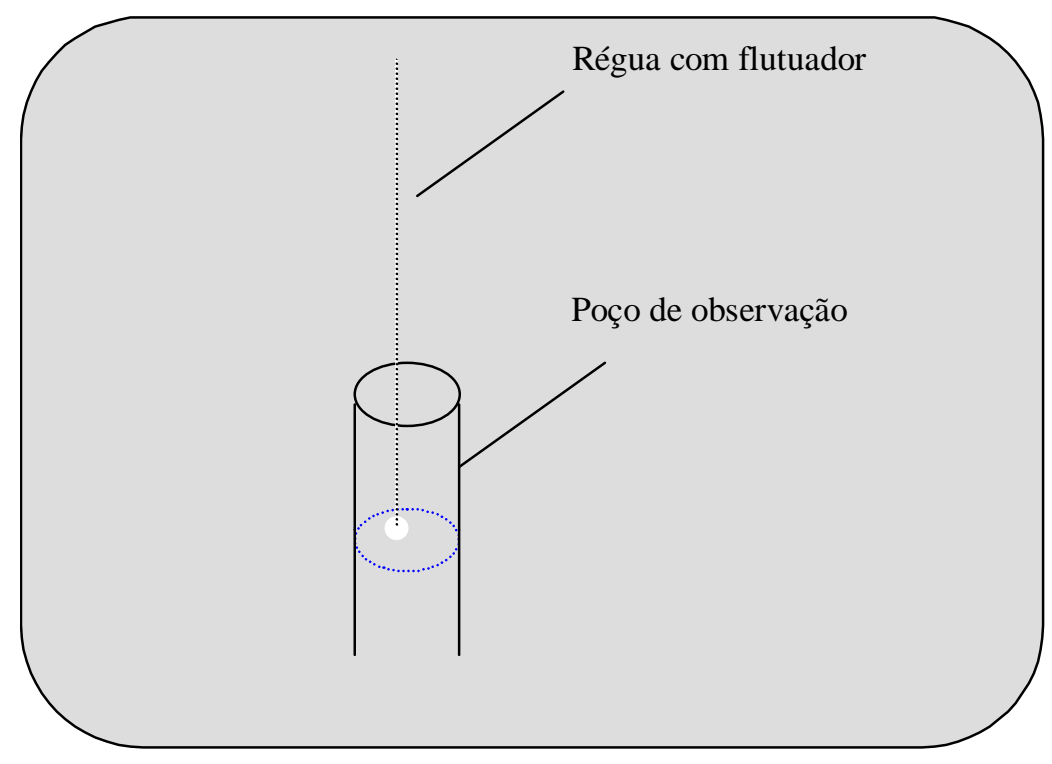

Figura 4 - Esquema dos elementos componentes do sistema de medição do nível do lençol freático

\subsection{Experimento com a cultura da batata}

\subsubsection{Amostragem do solo, análise do solo e adubação}

A coleta das amostras de solo dos 52 recipientes foi realizada em uma camada de solo de profundidade de 0 a $0,20 \mathrm{~m}$, com a ajuda de um trado tipo holandês; as mesmas foram misturadas homogeneamente para formar uma amostra composta única. Esta 
amostra foi analisada no Laboratório de Fertilidade de Solos do Departamento de Solos, Geologia e Fertilizantes da ESALQ/USP. A Tabela 3 apresenta os resultados da análise química dessa amostra.

Tabela 3. Análise química do solo utilizado no experimento com a cultura da batata

\begin{tabular}{|c|c|c|c|c|c|c|c|c|c|}
\hline \multirow{2}{*}{$\mathrm{pH}\left(\mathrm{CaCl}_{2}\right)$} & M.O. & $\mathrm{P}$ & $\mathrm{S}$ & $\mathrm{K}$ & Ca & $\mathrm{Mg}$ & $\mathrm{H}+\mathrm{Al}$ & $\mathrm{T}$ & \multirow{2}{*}{$\begin{array}{l}\mathrm{V} \\
\text { (\%) }\end{array}$} \\
\hline & $\left(\mathrm{g} \mathrm{dm}^{-3}\right)$ & \multicolumn{2}{|c|}{$\left(\mathrm{mg} \mathrm{dm}^{-3}\right)$} & \multicolumn{5}{|c|}{$\left(\right.$ mmolc dm $\left.{ }^{-3}\right)$} & \\
\hline 5.0 & 33 & 327 & 550 & 1,3 & 61 & 17 & 16 & 95,3 & 83 \\
\hline
\end{tabular}

Seguindo as recomendações da análise de solo fornecidas pelos técnicos do referido Departamento, o solo não precisou de calagem e a adubação foi parcelada em três oportunidades, ou seja, plantio, pré-emergência e amontoa.

A adubação para o plantio, realizada no dia 19 de julho, constou de $500 \mathrm{~kg} \mathrm{ha}^{-1}$ da formulação 12-00-24, o que representou 9,81 g por recipiente; $200 \mathrm{~kg} \mathrm{ha}^{-1}$ de superfosfato simples, representando 3,92 g por recipiente e $1 \mathrm{~kg} \mathrm{ha}^{-1}$ de boro, dando 0,02 $\mathrm{g}$ por recipiente.

Aos 16 dias após o plantio, ou seja, no dia 3 de agosto, foi realizada a adubação correspondente à pré-emergência, com 5,89 g por recipiente de sulfato de amônio (300 kg ha $\left.{ }^{-1}\right)$ e 4,51 g por recipiente de cloreto de potássio $\left(230 \mathrm{~kg} \mathrm{ha}^{-1}\right)$.

No dia 28 de agosto realizou-se a última adubação, na amontoa, quando a maioria das plantas atingiram uma altura em média de $0,30 \mathrm{~m}$, com 5,89 g por recipiente de sulfato de amônio (300 $\mathrm{kg} \mathrm{ha}^{-1}$ ) e 4,51 g por recipiente de cloreto de potássio (230 kg $\left.\mathrm{ha}^{-1}\right)$.

\subsubsection{Variedade e época de plantio}

O plantio da batata foi realizado no dia 19 de julho de 2001. Utilizou-se a variedade Itararé originária da estação experimental do Instituto Agronômico de Campinas (IAC), localizada na cidade de Itararé, SP. Esta variedade apresenta um desenvolvimento vegetativo mediano, hastes vigorosas e ciclo curto, estimado em 100 dias para a tem- 
porada de inverno. As batatas sementes foram fornecidas pelos técnicos do Departamento de Raízes e Tubérculos da Fazenda Santa Elisa do IAC.

Segundo os mesmos técnicos, a época recomendada para o plantio desta variedade de ciclo curto, especificamente para a região de Piracicaba, SP, vai de maio até junho. A demora no plantio para este experimento ocorreu em virtude da prioridade na provisão das batatas sementes ser dada aos produtores, e depois ao suprimento do pedido para este experimento.

Foram plantadas manualmente as batatas sementes inteiras, a uma profundidade de 0,10 m e com uma densidade de semeadura de 1 batata semente por recipiente ou 1 batata semente por $0,20 \mathrm{~m}^{2}$. Os tubérculos apresentavam um formato oblongo, com um peso médio de 70,75 g, com brotos de 0,075 m de comprimento, em média.

No dia 31 de julho iniciou-se a emergência das plantas dos primeiros recipientes, demorando em torno de 25 dias desde o plantio até atingir-se uma emergência de 90 $\%$, na data 13 de agosto de 2001.

\subsubsection{Dados meteorológicos}

O posto meteorológico do Departamento de Ciências Exatas da ESALQ/USP forneceu os dados de temperatura, umidade relativa, evaporação e precipitações ocorridas durante o período experimental.

\subsubsection{Manejo da Irrigação}

Seguindo o critério de simplicidade da metodologia do experimento, foi escolhido o método de irrigação por superfície, sendo a aplicação da lâmina de água necessária para a planta realizada com a ajuda de uma proveta graduada de $1000 \mathrm{~mL}$.

A princípio, a quantidade de lâmina de água aplicada foi baseada na função de produção para a cultura da batata estimada por Duarte (1989), dada por:

$Y(W)=28,31978+0,1818 W-0,0001452 W^{2}$ 
em que $\mathrm{Y}(\mathrm{W})$ é a produtividade, em $\mathrm{kg} \mathrm{ha}^{-1} \mathrm{e} \mathrm{W}$ é lâmina total de água aplicada durante o ciclo, em mm.

Derivando-se esta função e igualando-se a zero, obtém-se $626 \mathrm{~mm}$ de lamina de água total para atingir a máxima produção. Com a estimativa de um ciclo de 100 dias para a cultura da batata, obtém-se uma lâmina diária de aplicação média de 6,26 mm por cada recipiente. Tendo em vista que a área de cada recipiente é de $0,20 \mathrm{~m}^{2}$, chega-se a 1,3 litros de água por recipiente por dia, com um turno de rega de 1 dia. Este foi o volume de água aplicado até o dia 20 de setembro de 2001 aos 63 dias após a emergência.

Durante os tratamentos, as plantas submetidas a inundação não eram irrigadas, voltando a ser irrigadas no momento em que o nível do lençol freático atingia o fundo dos recipientes.

Iniciou-se uma nova etapa de controle da irrigação, no dia 19 de setembro, quando foram instalados tensiômetros em cada recipiente, a uma profundidade de $25 \mathrm{~cm}$, previamente testados no Laboratório de Solos do Departamento de Engenharia Rural da ESALQ/USP. A partir da instalação dos tensiômetros, efetuou-se a irrigação, somente quando as leituras dos tensiômetros localizados nos vasos que representavam as repetições de cada tratamento atingiam a tensão média de $17 \mathrm{kPa}$. Este valor representou o momento da irrigação, baseado nos parâmetros físicos da curva de retenção para o material de solo da serie "Sertãozinho" (Latossolo Vermelho Amarelo), de textura francoarenosa. Os parâmetros do modelo de van Genuchten (1980) para este tipo de solo, segundo Miranda (2001), são apresentados na Tabela 4.

Tabela 4 - Relação dos parâmetros do material de solo utilizado, para a entrada no modelo de Van Genuchten (1980), segundo Miranda (2001)

\begin{tabular}{ccccc}
\hline \multicolumn{5}{c}{ Parâmetros da curva de retenção do solo LVA “Sertãozinho” } \\
\hline$\theta r$ & $\theta$ s & $\alpha$ & $\mathrm{n}$ & $\mathrm{m}$ \\
$\left(\mathrm{cm}^{3} \mathrm{~cm}^{-3}\right)$ & $\left(\mathrm{cm}^{3} \mathrm{~cm}^{-3}\right)$ & $\left(\mathrm{cm}^{-1}\right)$ & (adimens.) & (adimens.) \\
0,162 & 0,443 & 0,0449 & 3,6732 & 0,1119 \\
\hline
\end{tabular}

Com estes parâmetros e as tensões de capacidade de campo (CC) e de ponto de 
murcha permanente (PMP), de 9 e $1500 \mathrm{kPa}$ respectivamente, assumiu-se o momento da irrigação para a cultura da batata quando a tensão atual atingisse o valor de $17 \mathrm{kPa}$, valor este correspondente a 30\% da quantidade de água disponível dentro da faixa de CC e PMP.

Assim sendo, para um volume de solo de $58905 \mathrm{~cm}^{3}$, determinado pela área resultante dos $50 \mathrm{~cm}$ de diâmetro interno do recipiente e profundidade de $30 \mathrm{~cm}$, determinou-se o volume de 1.797,3 $\mathrm{cm}^{3}$ de água a aplicar, ou seja 1,79 litros, equivalente a uma lâmina de água de 9,15 mm, volume este aplicado a uma freqüência média entre um e dois dias. Assim, com essa metodologia, respondeu-se as duas importantes questões: quando irrigar e quanto irrigar. As leituras dos tensiômetros foram realizadas diariamente, utilizando-se um tensímetro digital.

\subsubsection{Tratos culturais}

Devido a facilidade apresentada no experimento pela área reduzida dos recipientes e a pequena população de plantas, as culturas tiveram um trato cultural intensivo, sempre com o intuito de que, em cada operação realizada, se procurasse o menor contato direto com as plantas, devido ao fato destas apresentarem elevado grau de sensibilidade ao manuseio.

A limpeza de ervas daninhas foi executada manualmente, em forma periódica, sem representar substancialmente alguma capina importante propriamente dita.

No dia 17 de agosto houve o desfolhamento praticamente total de uma planta devido a um ataque severo de formigas saúvas, o que motivou a aplicação do inseticida Fipronil na data 20 de agosto com a dose de 9,5 gramas por 26 litros de água recomendada para a área de $10,4 \mathrm{~m}^{2}$, compreendida pelos 52 vasos, com a média de $500 \mathrm{~mL}$ de solução pulverizada em cada recipiente.

Observou-se no dia 21 de agosto o retorno das formigas saúvas, com um ataque ligeiro, o que motivou, ao não poder-se identificar o ninho das formigas, realizar uma demarcação do limite circular dos recipientes e do perímetro retangular da bateria dos 52 recipientes em total, constituída por uma barreira de 1 kg de pó do produto Del- 
tamethrin. Após esta providência não constatou-se mais, ao longo do ciclo da cultura, a ocorrência de ataques dessa natureza.

Ao longo do ciclo da batata e com a consciência de que a mesma se constituia em um alvo predileto para um amplo universo de insetos e doenças, na tentativa de se obter um êxito na safra, procedeu-se a um tratamento preventivo periódico com pulverizações de vários defensivos de amplo espectro, com preparados a partir de bactericidas, fungicidas e inseticidas, esquematizados na Tabela 5.

Tabela 5. Esquema de pulverizações realizadas durante o ciclo da cultura da batata

$$
\text { Datas (ano 2001) }
$$

Produtos

$$
\begin{array}{lllllllll}
\hline 22 / 08 & 28 / 08 & 31 / 08 & 12 / 09 & 17 / 09 & 21 / 09 & 28 / 09 & 5 / 10 & 12 / 10
\end{array}
$$

\begin{tabular}{lccccccccc}
\hline Óxido cloreto de cobre & $\mathrm{x}$ & $\mathrm{x}$ & $\mathrm{x}$ & $\mathrm{x}$ & $\mathrm{x}$ & $\mathrm{x}$ & $\mathrm{x}$ & $\mathrm{x}$ & $\mathrm{x}$ \\
Clorotalonil & $\mathrm{X}$ & $\mathrm{x}$ & $\mathrm{x}$ & $\mathrm{x}$ & $\mathrm{x}$ & $\mathrm{x}$ & $\mathrm{x}$ & $\mathrm{x}$ & $\mathrm{x}$ \\
Parathion metílico & $\mathrm{x}$ & $\mathrm{x}$ & $\mathrm{x}$ & $\mathrm{x}$ & $\mathrm{x}$ & $\mathrm{x}$ & $\mathrm{x}$ & $\mathrm{x}$ & $\mathrm{x}$ \\
Mancozeb & $\mathrm{x}$ & - & - & - & - & - & - & - & - \\
Clorpirifos & - & $\mathrm{x}$ & $\mathrm{x}$ & $\mathrm{x}$ & $\mathrm{x}$ & $\mathrm{x}$ & $\mathrm{x}$ & $\mathrm{x}$ & $\mathrm{x}$ \\
Deltamethrin & - & $\mathrm{x}$ & - & - & - & - & - & - & - \\
Abamectina & - & - & - & - & - & $\mathrm{x}$ & $\mathrm{x}$ & $\mathrm{x}$ & $\mathrm{x}$ \\
\hline
\end{tabular}

As pulverizações descritas anteriormente contribuíram para que ao longo do ciclo da batata não fossem observados, nas parte aérea das plantas, quaisquer sintomas de infeções causadas por fungos, bactérias e vírus. Ocorreram apenas algumas pintas escuras, não identificadas pelos técnicos da Clinica do Departamento de Fitopatologia, Entomologia e Zoologia da ESALQ, levando a suposição de que as mesmas seriam seqüelas da fitotoxicidade ocasionada pela aplicação, em excesso, de alguns defensivos ou a ocorrência de sinergismo pela mistura dos mesmos quando pulverizados em conjunto na cultura.

Além do mencionado ataque de saúvas, em um número reduzido de plantas, observou-se vestígios de ataque de mosca minadora de folhas (Lyriomyzas sp.). Trata- 
vam-se de pequenas galerias abandonadas apresentadas nas folhas de algumas plantas.

\subsubsection{Colheita da batata}

A colheita foi realizada manualmente, utilizando-se uma pá reta, à medida que os sintomas de maturação foram se apresentando, nos dias 21, 23, 27 e 29 de outubro, completando os ciclos de 95, 97, 101 e 103 dias respectivamente, observando-se um ciclo menor nas plantas nas quais foram aplicados os tratamentos de inundação.

\subsubsection{Tratamentos e delineamento experimental para a cultura da batata}

Na cultura da batata, os tratamentos mencionados anteriormente, relativos às diferentes velocidades de rebaixamento, foram executados em três estádios de desenvolvimento das plantas, representando diferentes etapas do crescimento das mesmas. A inundação no primeiro estágio iniciou-se aos 31 dias após o plantio; a inundação do estádio seguinte, aos 61 dias; a terceira inundação aos 85 dias, diferindo do intervalo entre as duas inundações anteriores pela razão de observar-se sintomas na parte aérea das plantas de um amadurecimento adiantado das mesmas.

Segundo a classificação FAO (1979) para os estádios de crescimento da batata, a primeira inundação foi aplicada no inicio da fase III, denominada desenvolvimento vegetativo, estolonização e tuberização, em que a necessidade de água é uma das mais acentuadas. A segunda inundação foi executada na metade da fase IV, de estolonização, tuberização e desenvolvimento de tubérculos. O último encharcamento ocorreu na fase de desenvolvimento dos tubérculos e maturação.

Assim, os tratamentos foram definidos por: tempo de rebaixamento do lençol freático, desde uma altura inicial tangente à superfície do solo até atingir a profundidade de 0,30 m; inundações realizadas em 3 estádios de desenvolvimento; mais uma testemunha na qual não foram realizadas inundações, utilizando-se 4 repetições, ou seja: 
$\mathrm{V}_{1}$ - rebaixamento a $30 \mathrm{~cm}$ de profundidade em 24 horas

$\mathrm{V}_{2}$ - rebaixamento a $30 \mathrm{~cm}$ de profundidade em 48 horas

$\mathrm{V}_{3}$ - rebaixamento a $30 \mathrm{~cm}$ de profundidade em 72 horas

$\mathrm{V}_{4}$ - rebaixamento a $30 \mathrm{~cm}$ de profundidade em 96 horas

$\mathrm{P}_{1}$ - aplicação dos tratamentos no estádio 1

$\mathrm{P}_{2}$ - aplicação dos tratamentos no estádio 2

$\mathrm{P}_{3}$ - aplicação dos tratamentos no estádio 3

$\mathrm{T}$ - testemunha sem encharcamento

Totalizou-se, assim, a quantidade de 52 recipientes-parcelas destinados para o desenvolvimento do experimento.

O delineamento estatístico adotado foi o inteiramente casualizado, em esquema fatorial ( 4 velocidades X 3 estádios + 1 testemunha). A Tabela 6 apresenta as causas de variação e os respectivos graus de liberdade da análise de variância. Para testar a significância na análise de variância foi realizado o teste F e para a comparação das médias entre os tratamentos foi empregado o teste de Duncan, em nível de 5\% de probabilidade.

Tabela 6. Esquema da análise de variância utilizada para a cultura da batata

\begin{tabular}{lc}
\hline Causas de Variação & Graus de Liberdade \\
\hline Testemunha & 1 \\
Velocidade de Rebaixamento & 3 \\
Período de Aplicação & 2 \\
Interação Velocidade x Período & 6 \\
Tratamentos & 12 \\
Resíduo & 39 \\
Total & 51 \\
\hline
\end{tabular}

\subsubsection{Avaliação dos parâmetros relativos à produção da batata}

Ao final do ciclo da cultura foram colhidos os tubérculos e realizada a medição dos seguintes parâmetros: peso fresco total dos tubérculos, peso seco total dos tubércu- 
los, peso fresco dos tubérculos sadios, peso fresco dos tubérculos comerciais, peso fresco dos tubérculos por classe comercial e número total de tubérculos.

O peso fresco total dos tubérculos foi determinado em balança de precisão de 0,1 mg, no momento imediato após a colheita. Foram considerados sadios os tubérculos isentos de anormalidades fisiológicas ( embonecamento, rachaduras, unhaduras e esverdeamento) e de podridões causadas por Fusarium sp. ou Erwinia sp. Os tubérculos considerados comerciais foram os sadios cujo menor diâmetro fosse maior que $20 \mathrm{~mm}$. A classificação comercial tomou por base a Portaria n ${ }^{0} 307$ do Ministério da Agricultura (EMBRATER, 1982), que estabelece quatro classes comerciais, baseadas no menor diâmetro do tubérculo (Tabela 7). Após sua classificação comercial, os tubérculos foram secos em estufa a $60-62{ }^{\circ} \mathrm{C}$ e pesados em balança de precisão de $0,1 \mathrm{mg}$, até alcançarem peso constante, visando a obtenção do peso seco total.

Tabela 7. Classificação comercial dos tubérculos, segundo a Portaria n ${ }^{0} 307$ do Ministério da Agricultura (EMBRATER, 1982)

\begin{tabular}{cc}
\hline Classe comercial & Diâmetro mínimo (mm) \\
\hline Graúda & Maior que 45 \\
Média & Entre 33 e 45 \\
Miúda & Entre 23 e 33 \\
Miudinha & Entre 20 e 23 \\
\hline
\end{tabular}

\subsection{9 - Relação entre a produtividade relativa da batata e o índice diário de estresse (IDS)}

A produtividade relativa foi calculada em relação à produtividade comercial da testemunha, ou seja, considerou-se esta igual a 100\%. Para o cálculo dos valores do índice diário de estresse (IDS) relativos aos tratamentos, foi utilizada a equação 2.

O fator de estresse diário (SD) foi estimado tomando como base a sugestão de Hardjoamidjojo et al. (1982) e Skaggs (1990), ou seja, considerou-se SD = SEW 30 . Apli- 
cando-se a equação 1, para os valores de posição do nível freático apresentados na Tabela 2, encontram-se os seguintes valores de $\mathrm{SEW}_{30}$ para as quatro velocidades de rebaixamento adotadas: 21,15; 34,20; 47,35 e 60,45 cm dia, para as velocidades $V_{1}, V_{2}, V_{3}$ e $\mathrm{V}_{4}$, sendo $\mathrm{SEW}_{30}=0$ para a testemunha.

O fator de sensibilidade da cultura (SC) foi calculado pela equação 3. Desta forma, combinando-se quatro valores de $\mathrm{SEW}_{30}$ com três valores de SC, mais a testemunha (IDS=0), foram obtidos 13 valores de IDS, valores estes que foram correlacionados com as produtividades relativas (YT). Optou-se pelo modelo de regressão linear e impôs-se também a condição da reta passar no ponto $\mathrm{Y}=100 \%$ e IDS=0, o que corresponde ao valor da testemunha.

\subsection{Experimento com a cultura da Alface}

\subsubsection{Amostragem do solo, análise do solo e adubação}

A coleta das amostras do solo dos 52 recipientes foi realizada de uma camada de solo de profundidade de 0 a 0,20 m, com a ajuda do trado tipo holandês, misturadas homogeneamente para formar uma amostra única composta. Esta amostra foi analisada no Laboratório de Fertilidade do Solo do Departamento de Solos, Geologia e Fertilizantes da ESALQ/USP. A Tabela 8 apresenta os resultados da análise química dessa amostra.

Tabela 8 - Análise química do solo utilizado no experimento com a cultura da alface

\begin{tabular}{|c|c|c|c|c|c|c|c|c|c|}
\hline \multirow{2}{*}{$\mathrm{pH}\left(\mathrm{CaCl}_{2}\right)$} & M.O. & $\mathrm{P}$ & $S$ & $\mathrm{~K}$ & $\mathrm{Ca}$ & $\mathrm{Mg}$ & $\mathrm{H}+\mathrm{Al}$ & $\mathrm{T}$ & \multirow{2}{*}{$\begin{array}{c}\mathrm{V} \\
\text { (\%) }\end{array}$} \\
\hline & $\left(\mathrm{g} \mathrm{dm}^{-3}\right)$ & \multicolumn{2}{|c|}{$\left(\mathrm{mg} \mathrm{dm}^{-3}\right)$} & \multicolumn{5}{|c|}{$\left(\right.$ mmolc dm $\left.{ }^{-3}\right)$} & \\
\hline 5.6 & 16 & 357 & 623 & 15.2 & 69 & 16.2 & 16 & 115 & 87 \\
\hline
\end{tabular}

Seguindo as recomendações da análise de solo fornecidas pelos técnicos do referido Departamento, o solo não precisou de calagem e a adubação foi parcelada em quatro oportunidades, ou seja, no transplante, aos 10, 20 e 30 dias após do transplante. 
A adubação para o transplante constou de $165 \mathrm{~kg} \mathrm{ha}^{-1}$ de cloreto de potássio $\left(60 \% \mathrm{~K}_{2} \mathrm{O}\right)$ ou seja $3,3 \mathrm{~g}$ por recipiente; $90 \mathrm{~kg} \mathrm{ha}^{-1}$ de uréia ou 1,8 g por recipiente; 550 $\mathrm{kg} \mathrm{ha}^{-1}$ de superfosfato simples ou $11 \mathrm{~g}$ por recipiente e $1 \mathrm{~kg} \mathrm{ha}^{-1}$ de boro, dando 0,02 g por recipiente.

As adubações seguintes foram realizadas com uréia na dose de $150 \mathrm{Kg} \mathrm{ha}^{-1}$ (3 g por recipiente) nos dias 17/12/2001, 27/12/2001 e 6/01/2002, ou seja aos 10, 20 e 30 dias após o transplante.

\subsubsection{Variedade e época de plantio}

O transplante da alface (Lactuca sativa L.) variedade crespa, denominada comercialmente como Verônica, adaptada para o plantio de verão, foi realizado em 8 de dezembro de 2001, com mudas de cerca de 24 dias, fornecidas por um viverista especializado.

A densidade de transplante foi de 3 plantas por recipiente ou 3 plantas por 0,20 $\mathrm{m}^{2}$. Após o raleio, as parcelas ficaram com a densidade final de 1 planta por recipiente.

\subsubsection{Dados meteorológicos}

Tal qual o ocorrido durante o ciclo da cultura da batata, o posto meteorológico do Departamento Ciências Exatas da ESALQ/USP forneceu os dados de temperatura, umidade relativa, evaporação e precipitações ocorridas durante o período experimental.

\subsubsection{Manejo da Irrigação}

Utilizou-se o método de irrigação por superfície, sendo a aplicação da lâmina de água necessária para a planta realizada com a ajuda de uma proveta graduada de 1000 $\mathrm{mL}$.

Com um turno de rega de 1 dia, aplicou-se uma lâmina de irrigação variável resultante da diferença da leitura atual do tensiômetro e a tensão 9 kPa, correspondente à 
capacidade de campo para esse material de solo, considerando-se como profundidade efetiva das raízes $20 \mathrm{~cm}$. As leituras dos tensiômetros foram realizadas diariamente, utilizando-se um tensímetro digital.

\subsubsection{Tratos culturais}

Tal qual realizado na cultura da batata, as plantas tiveram um trato cultural intensivo, sempre com o intuito de fazer o menor contato com as plantas, para não imprimir nenhum tipo de lesão que perturbasse o desenvolvimento normal da cultura e não desse lugar a passagem de patógenos.

A limpeza de ervas daninhas foi executada manualmente, de forma periódica, sem representar substancialmente alguma capina importante propriamente dita.

Ao contrário da cultura da batata, a alface não precisou de aplicação de nenhum tipo de defensivo, não se observando nenhum sintoma que denotasse a ação de doenças e pragas.

Por causa das fortes chuvas acontecidas no início do experimento morreram algumas plantas, impossibilitando a concretização da população necessária para completar todas as repetições definidas a principio para todos os tratamentos.

No final do ciclo da alface observou-se sintomas de queima das bordas nas plantas correspondentes as repetições do tratamento $\mathrm{V}_{4}$ (velocidade de rebaixamento mais lenta), o que possivelmente está relacionada a uma doença fisiológica causada pela má translocação de cálcio (Ryder, 1979).

\subsubsection{Colheita da alface}

A colheita foi realizada manualmente ao completar-se 41 dias após o transplante. O prolongamento da duração do ciclo para além das cinco semanas após o transplantio, geralmente recomendado para a colheita desta hortaliça, deveu-se à duração dos tratamentos aplicados à cultura. 


\subsubsection{Tratamentos e delineamento experimental para a cultura da alface}

Na cultura da alface os tratamentos foram executados em três estádios de desenvolvimento das plantas, representando diferentes etapas do crescimento das mesmas, em intervalos de 10 dias.

A inundação do primeiro estádio iniciou-se no dia 19 de dezembro, aos 12 dias após do transplante; a inundação do estádio seguinte no dia 29 de dezembro, aos 22 dias e a terceira inundação no dia 8 de janeiro, aos 32 dias após do transplante.

Os tratamentos foram os mesmos realizados para a cultura da batata, ou seja, 4 velocidades de rebaixamento do nível freático (30 cm em 24, 48, 72 e 96 horas), inundações aplicadas em 3 estádios, mais uma testemunha na qual não foi aplicado o estresse por elevação do nível freático. Entretanto, foram realizadas apenas três repetições devido à perda de plantas ocasionada pelas chuvas intensas ocorridas durante o período experimental. Assim, utilizou-se o delineamento inteiramente casualizado, com esquema em fatorial ( 4 × $3+1$ ), ou seja, 13 tratamentos com 3 repetições, totalizando 39 recipientes-parcelas. Houve também uma parcela perdida, de forma que a análise de variância, com as causas da variação e seus respectivos graus de liberdade, ficou estabelecida conforme apresentada na Tabela 9.

Tabela 9. Esquema da análise de variância utilizada para o experimento com a cultura da alface

\begin{tabular}{lc}
\hline Causa de variação & Graus de liberdade \\
\hline Testemunha & 1 \\
Velocidade de Rebaixamento & 3 \\
Período de Aplicação & 2 \\
Interação Velocidade x Período & 6 \\
Tratamentos & 12 \\
Resíduo & 25 \\
Total & $37\left(^{*}\right)$ \\
\hline
\end{tabular}

(*) Devido ocorrer uma parcela perdida o grau de liberdade total do experimento foi de 37 ao invés de 38. 
Tal como se procedeu com a cultura da batata, realizou-se o teste F na análise de variância e o teste de Duncan, em nível de 5\% de probabilidade, para comparação da média entre os tratamentos.

\subsubsection{Avaliação dos parâmetros vegetativos e da produção da alface}

No momento da colheita foram medidos os seguintes parâmetros da cultura: altura da planta, diâmetro da parte aérea (diâmetro da “cabeça”) e diâmetro do caule. Imediatamente após da colheita pesou-se as folhas e o caule, em balança de precisão de 0,1 mg, para determinação do peso fresco.

O peso seco da parte aérea das plantas foi determinado pela pesagem de folhas e caule, em balança de precisão de 0,1 mg, após secagem em estufa com circulação forçada do ar a $60-62^{\circ} \mathrm{C}$, até atingir peso constante.

\subsubsection{Relação entre a produtividade relativa da alface e o índice diário de estresse (IDS)}

A produtividade relativa da alface foi estimada tomando como base o valor do peso verde médio da parte aérea da testemunha, considerado como sendo 100\%. Os valores do IDS foram calculados tal como foi descrito para a cultura da batata (item 3.6.9). 


\section{RESULTADOS E DISCUSSÃO}

\subsection{Experimento com a cultura da batata}

\subsubsection{Parâmetros climáticos medidos ao longo do ciclo da batata}

O plantio das batatas semente foi realizado no dia 19 de julho de 2001, sendo a última colheita efetuada no dia 29 de outubro do mesmo ano, ou seja, 103 dias após o plantio. Na Tabela 10 são apresentados os dados climáticos medidos durante este período no Posto Meteorológico do Departamento de Ciências Exatas da ESALQ/USP, localizado a cerca de 500 m da área na qual foi conduzido o experimento.

Tabela 10. Parâmetros climáticos medidos durante o ciclo da cultura da batata

\begin{tabular}{lc}
\hline Parâmetro & Valor medido \\
\hline Temperatura máxima média $\left({ }^{\circ} \mathrm{C}\right)$ & 28,0 \\
Temperatura mínima média $\left({ }^{\circ} \mathrm{C}\right)$ & 14,1 \\
Temperatura média $\left({ }^{\circ} \mathrm{C}\right)$ & 21,1 \\
Umidade relativa média (\%) & 67,8 \\
Precipitação total (mm) & 290,0 \\
Evaporação total (mm) & 427,3 \\
\hline
\end{tabular}

Os dados da série histórica completa do Posto Meteorológico da ESALQ/USP (1917 a 2003), para os meses de agosto, setembro e outubro, revelam dados médios de 
temperatura máxima, mínima e média de 28,5; 13,6 e 21,3; respectivamente. Desta forma, verifica-se que em relação às temperaturas, o período compreendido pelo ciclo da batata foi bastante típico. No que diz respeito às precipitações, a série histórica apresenta um valor médio de 2,2 $\mathrm{mm} \mathrm{d}^{-1}$, para os meses de agosto, setembro e outubro. $\mathrm{O}$ valor médio observado ao longo dos 103 dias do ciclo foi de $2,8 \mathrm{~mm} \mathrm{~d}^{-1}$, ou seja, foi um período relativamente mais chuvoso que o normal. Como consequência, a umidade relativa média observada no período (67,8\%) revelou-se ligeiramente acima da média histórica, que para os citados meses é de 66,3\%.

\subsubsection{Produtividade da batata e seus componentes}

O resultado da análise de variância para as variáveis peso verde total de tubérculos (PVT), peso seco total de tubérculos (PST), número total de tubérculos (NT), peso verde de tubérculos sadios (PVS) e peso verde comercial de tubérculos (PVC) está apresentado de forma resumida na Tabela 11. Pode-se observar que não houve nenhuma variável que apresentou a interação velocidade x período com um valor F significativo em nível de pelo menos 5\% de probabilidade. Verifica-se também que para todas as variáveis analisadas, com exceção do NT, houve diferença entre a testemunha e pelo menos um dos outros tratamentos envolvidos, em nível de $1 \%$ de probabilidade. No que diz respeito ao fator período, somente para a variável PVT não se obteve um valor de F que não fosse significativo a pelo menos 5\% de probabilidade. Já para o fator velocidade, só não foram encontradas diferenças significativas para a variável NT.

Os valores das médias das variáveis analisadas são apresentados na forma de gráficos (Figuras 5, 6, 7, 8 e 9). Nestes gráficos as letras sobre as colunas representam o resultado do teste de comparação de médias de Duncan, realizado a 5\% de significância, dentro de cada fator (períodos e velocidades) isoladamente, o que foi possível de ser feito devido ao fato das interações entre os fatores não terem sido significativas.

Observando-se os resultados do teste de comparação de médias de Duncan para a variável PVT, apresentados na Figura 5, pode-se avaliar que houve diferença significativa entre a testemunha e os diferentes tratamentos relativos às velocidades de 
Tabela 11. Valores de F e da probabilidade do efeito ter se dado ao acaso (entre parênteses) para as variáveis peso verde total de tubérculos (PVT), peso seco total de tubérculos (PST), número total de tubérculos (NT), peso verde de tubérculos sadios (PVS) e peso verde comercial de tubérculos (PVC)

\begin{tabular}{cccccc}
\hline \multirow{2}{*}{ Causas de Variação } & PVT & PST & NT & PVS & PVC \\
\hline Testemunha vs to- & $23,52 * *$ & $23,79 * *$ & 3,81 & $25,01^{* *}$ & $25,05^{* *}$ \\
dos & $(<0,0001)$ & $(<0,0001)$ & $(0,0582)$ & $(<0,0001)$ & $(<0,0001)$ \\
Velocidade & $3,50^{*}$ & $5,76^{* *}$ & 0,08 & $3,13^{*}$ & $3,22^{*}$ \\
& $(0,0242)$ & $(0,0023)$ & $(0,9694)$ & $(0,0365)$ & $(0,0329)$ \\
Período & 2,29 & $3,87^{*}$ & $4,00 *$ & $3,60 *$ & $3,66 *$ \\
Interação velocida- & $(0,1144)$ & $(0,029)$ & $(0,0263)$ & $(0,0368)$ & $(0,0350)$ \\
de*período & 0,82 & 1,07 & 0,59 & 0,58 & 0,62 \\
\hline
\end{tabular}

* - Significativo em nível de $5 \%$ de probabilidade.

** - Significativo em nível de $1 \%$ de probabilidade.
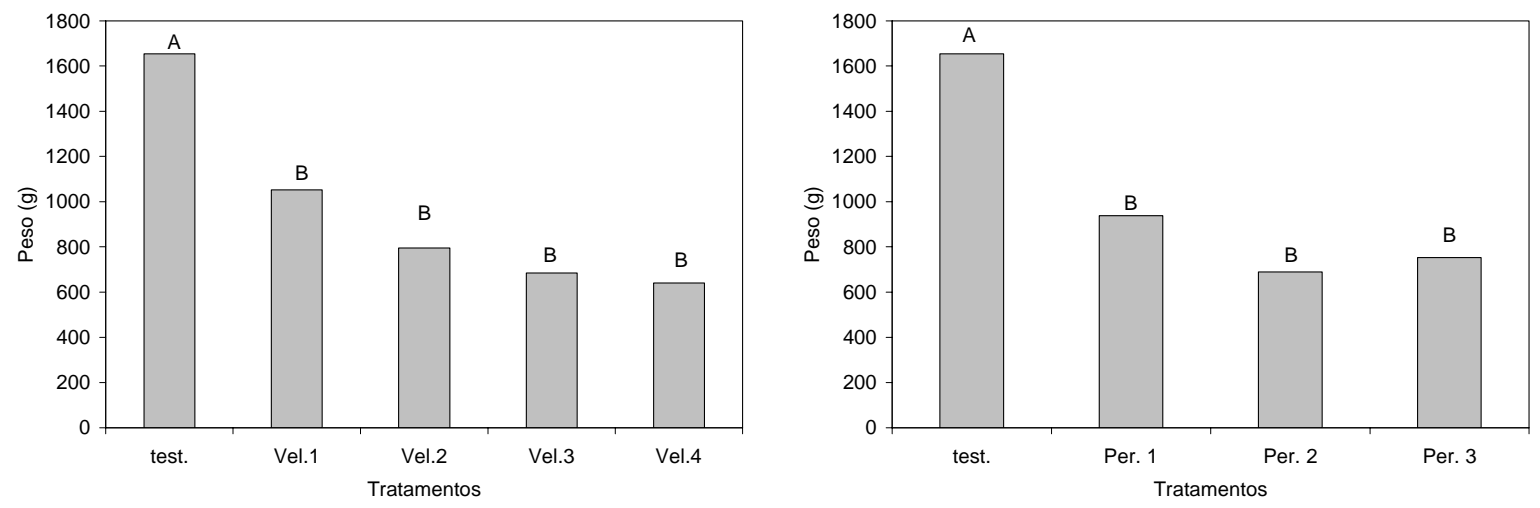

Figura 5 - Médias do peso verde total de tubérculos por planta de batata (PVT), segundo os diferentes tratamentos

rebaixamento e entre esta e os tratamentos relativos aos diferentes períodos de aplicação do encharcamento. Quando se compara as quatro velocidades de rebaixamento, independentemente da testemunha, o teste de Duncan não consegue acusar diferenças entre as mesmas, embora estas tenham sido identificadas no teste F. Isto possivelmente ocorre devido ao fato das diferenças entre as médias dos tratamentos do fatorial e a média da testemunha terem sido muito discrepantes, ocasionando uma diferença significativa no teste F. No que diz respeito às velocidades, verifica-se que a tendência observada foi de 
haver uma diminuição do PVT à medida em que as velocidades de rebaixamento se tornaram mais lentas. No que se refere ao efeito dos períodos de aplicação, não se pode detectar uma tendência nítida.

As médias do peso seco total dos tubérculos (PST) para os diferentes tratamentos são apresentadas na Figura 6. Como esperado, a proporção entre as média da testemunha e a dos diferentes tratamentos é aproximadamente a mesma observada para a variável PVT. Calculando-se a razão entre o peso seco e o peso verde, verifica-se que esta é de 21,2\% no caso da testemunha e que existe uma ligeira tendência de decréscimo para os tratamentos com velocidades de rebaixamento mais lentas, atingindo 17,9\% para V4.
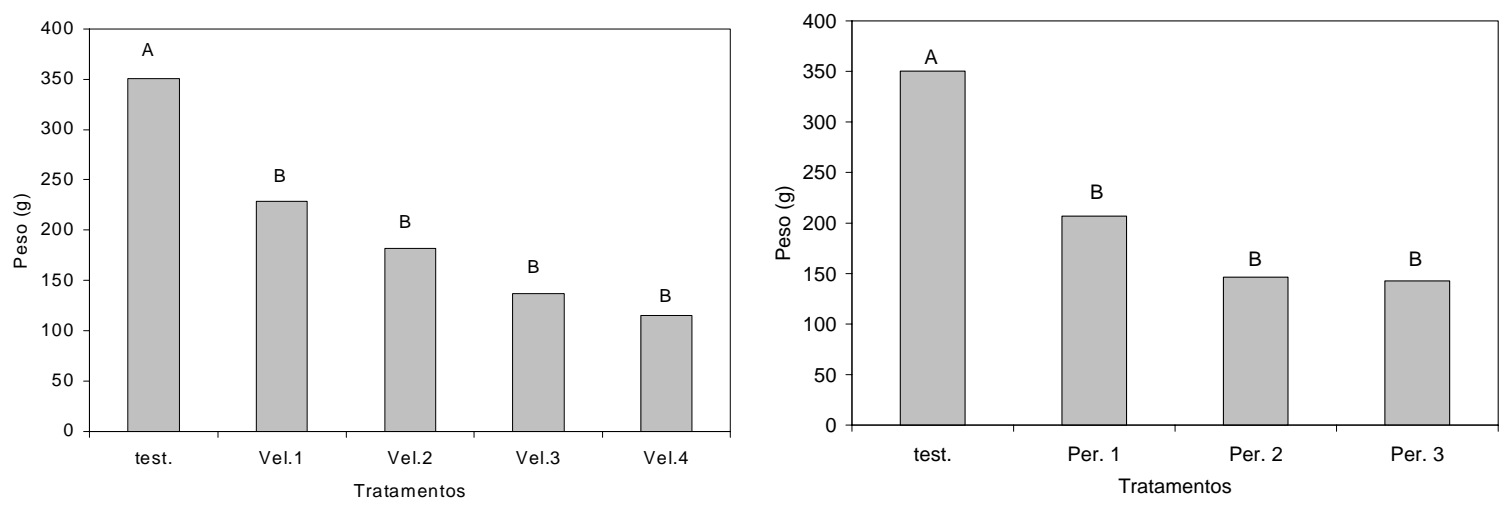

Figura 6 - Médias do peso seco total de tubérculos por planta de batata (PST), segundo os diferentes tratamentos

Quanto à variável número de tubérculos por planta (NT), cujas médias são apresentadas na Figura 7, pode-se observar que a testemunha proporcionou um número significativamente maior de tubérculos do que os tratamentos que sofreram encharcamento. No que diz respeito ao efeito das diferentes velocidades de rebaixamento, não é possível se identificar qualquer tipo de tendência. Já no que se refere ao efeito dos períodos de aplicação, verifica-se que o primeiro e principalmente o último período foram os que acarretaram maior redução no número de tubérculos, muito embora esta redução não tenha sido significativa pelo teste de Duncan. 

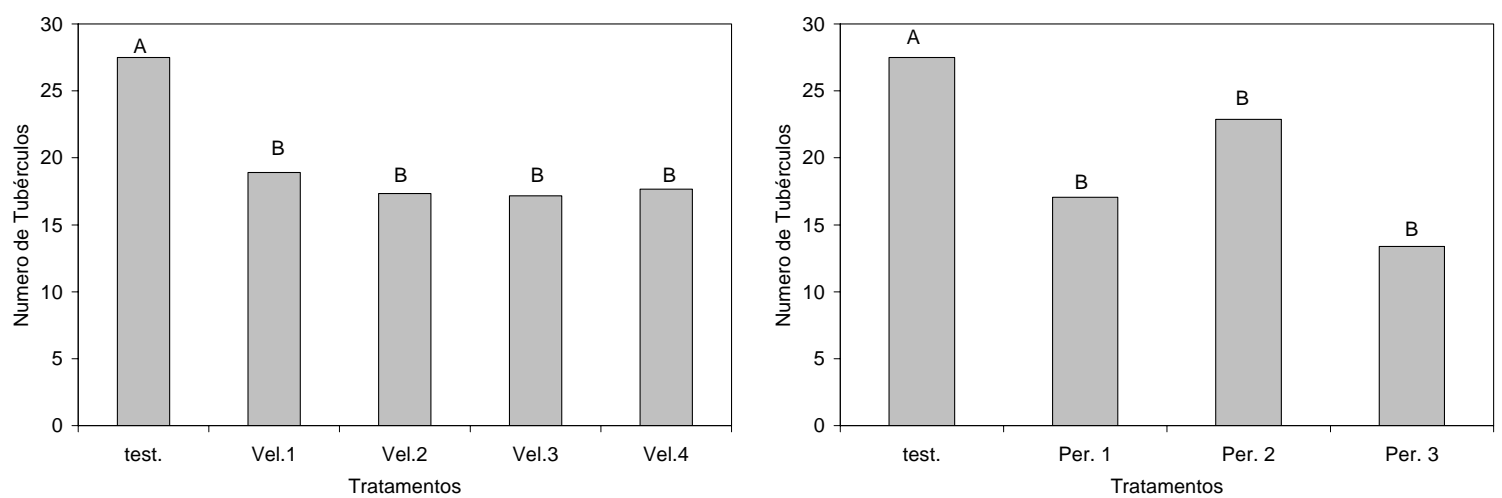

Figura 7 - Médias do número de tubérculos por planta de batata (NT), segundo os diferentes tratamentos

Este resultado não está em concordância com o apresentado no teste F, possivelmente pela mesma razão abordada na discussão dos efeitos dos tratamentos sobre o PVT.

A Figura 8 apresenta o resultado do teste de comparação de médias de Duncan para a variável peso verde dos tubérculos sadios (PVS). Comparando-se esta figura com a Figura 5, relativa à variável PVT, verifica-se que a diferença entre a testemunha e os diferentes tratamentos que sofreram encharcamento é maior na variável PVS, ou seja, além de reduzir a produção, o encharcamento acarretou um aumento da incidência de doenças e distúrbios fisiológicos. Assim, a razão entre PVS e PVT, ou seja, a percentagem dos tubérculos que se apresentaram sadios, foi de 97,5\% para a testemunha, enquanto que para os tratamentos V1 e V4, por exemplo, foi de 80,9 e 58,0\%, respectivamente.

O resultado dos tratamentos sobre a variável peso verde dos tubérculos comerciais (PVC) é apresentado na Figura 9. Pode-se observar que o efeito dos tratamentos sobre esta variável é mais drástico que para a variável PVT, ou seja, o encharcamento acarreta uma redução maior no peso dos tubérculos comerciais do que no peso total dos tubérculos. Assim, a razão entre a de V1 e a média da testemunha na variável PVT é de 63,6\%, enquanto que para a variável PVC esta razão é de apenas 52,7\%. Considerando-se que o PVC seja a variável economicamente mais importante, verifica-se que 

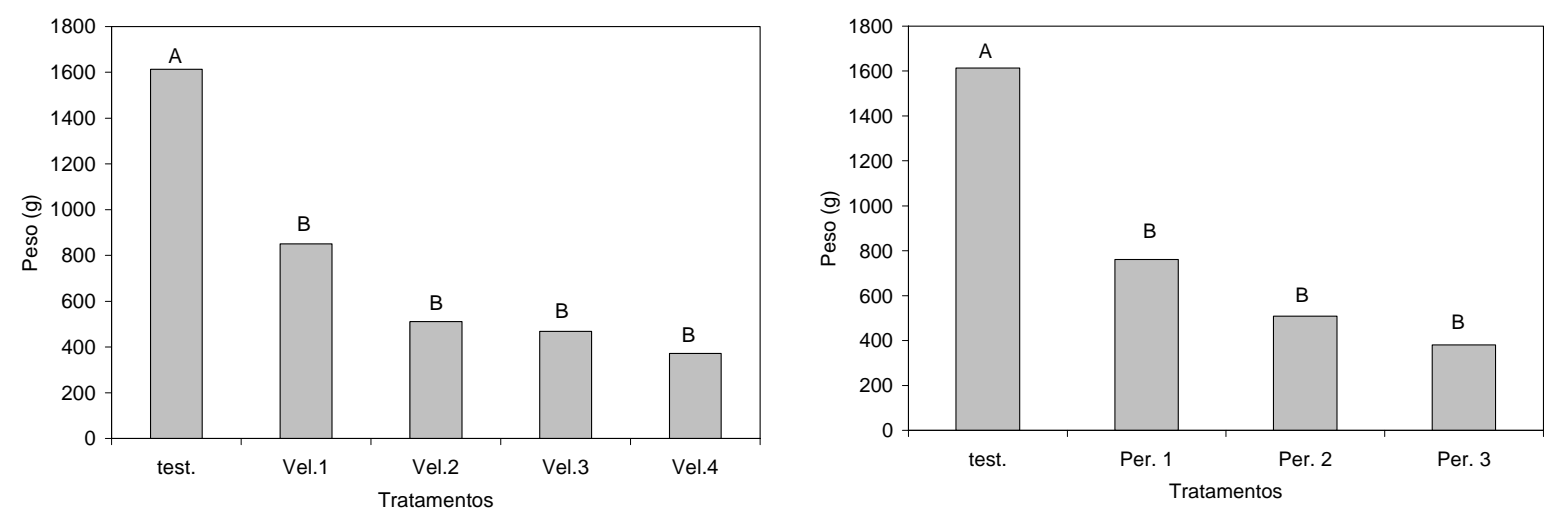

Figura 8 - Médias do peso verde de tubérculos sadios por planta de batata (PVS), segundo os diferentes tratamentos
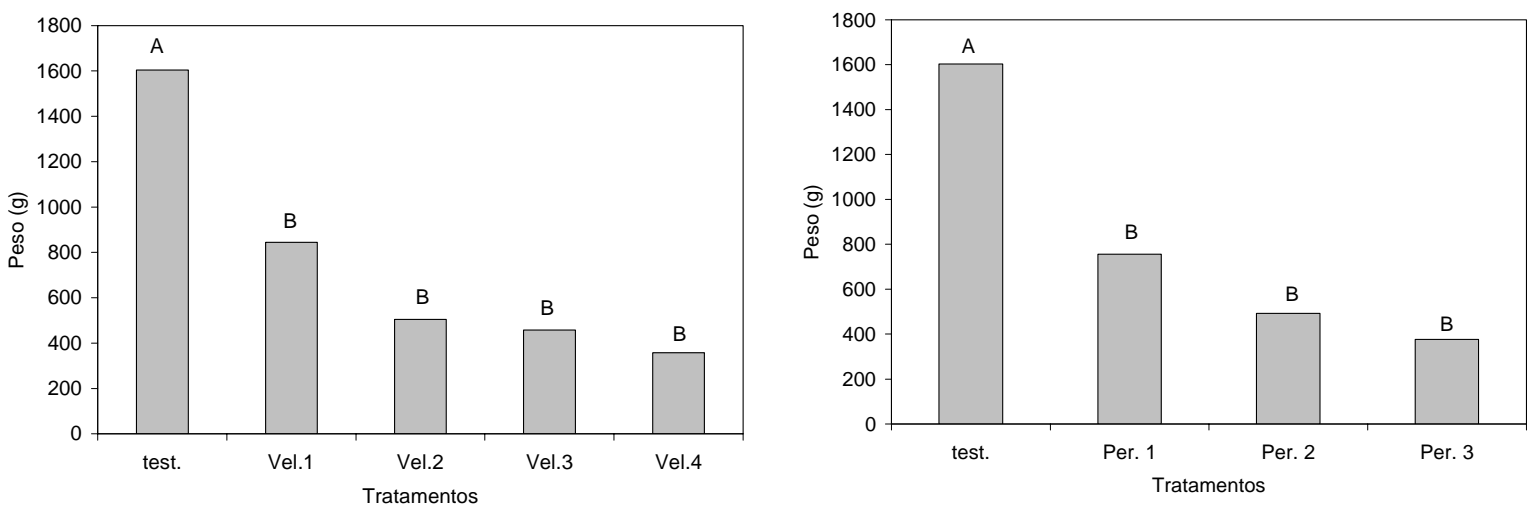

Figura 9 - Médias do peso verde de tubérculos comerciais por planta de batata (PVC), segundo os diferentes tratamentos

mesmo com a velocidade de rebaixamento mais alta ( $\mathrm{V} 1=30 \mathrm{~cm}$ em 1 dia) o peso verde comercial foi cerca da metade do PVC da testemunha. Portanto, para a cultura da batata, há necessidade de se testar velocidades de rebaixamento ainda maiores para se definir o valor do coeficiente de drenagem. Quanto aos períodos de aplicação do encharcamento, embora o teste de Duncan não revele diferenças entre estes, diferença esta acusada no teste F, verifica-se que o período 3 apresenta-se como o mais crítico.

O resultado da análise de variância para o peso verde dos tubérculos sadios segundo as diferentes classes comerciais é apresentado de forma resumida na Tabela 12. 
Tabela 12. Valores de F e da probabilidade do efeito ter se dado ao acaso (entre parênteses) para o peso verde dos tubérculos sadios, segundo o menor diâmetro das diferentes classes comerciais

\begin{tabular}{cccccc}
\hline \multirow{2}{*}{ Causas de Variação } & $>45$ & de 33 a 45 & de 23 a 33 & de 20 a 23 & $<20$ \\
\hline Testemunha vs to- & $24,25^{* *}$ & 3,94 & 1,89 & 0,24 & 0,99 \\
dos & $(<0,0001)$ & $(0,0542)$ & $(0,1772)$ & $(0,6267)$ & $(0,3269)$ \\
Velocidade & $4,31^{*}$ & 0,51 & 0,42 & 0,69 & $3,85^{*}$ \\
& $(0,0204)$ & $(0,6054)$ & $(0,6591)$ & $(0,5060)$ & $(0,0309)_{-}$ \\
Período & $3,19 *$ & 1,70 & 0,05 & 1,26 & $3,03^{*}$ \\
Interação velocida- & $(0,0342)$ & $(0,1832)$ & $(0,9836)$ & $(0,3029)$ & $(0,0423)$ \\
de*período & $(0,650$ & 0,91 & 0,97 & 0,76 & 1,99 \\
\hline
\end{tabular}

* - Significativo em nível de $5 \%$ de probabilidade.

** - Significativo em nível de $1 \%$ de probabilidade.

Pode-se observar que só houve diferenças significativas para as classes graúda (diâmetro mínimo > $45 \mathrm{~mm}$ ) e excessivamente pequena (diâmetro mínimo < $20 \mathrm{~mm}$ ). Verifica-se também que estas duas classes não apresentaram a interação velocidade $\mathrm{x}$ período com um valor $\mathrm{F}$ significativo em nível de pelo menos 5\% de probabilidade, o que permite analisar o efeito dos fatores experimentais isoladamente, tal como foi realizado anteriormente.

Observando-se os resultados do teste de comparação de médias de Duncan para o peso verde dos tubérculos graúdos sadios ( $>45 \mathrm{~mm}$ ), apresentados na Figura 10, pode-se verificar que a tendência é semelhante àquela observada na variável PVS (Figura 8). Isto significa que o efeito adverso do encharcamento deu-se principalmente na redução do peso da classe dos tubérculos de maior tamanho, mantendo aproximadamente a mesma percentagem de contribuição desta classe para o total dos tubérculos sadios. Assim, para a testemunha, a classe graúda representa 76,4\% do PVS, enquanto que V1 e V4, por exemplo, representam 71,2 e 78,0\%, respectivamente. Analisando-se o número médio de tubérculos e o peso médio dos tubérculos desta classe, verifica-se que a redução no PVS causada pelo encharcamento deve-se à diminuição do 

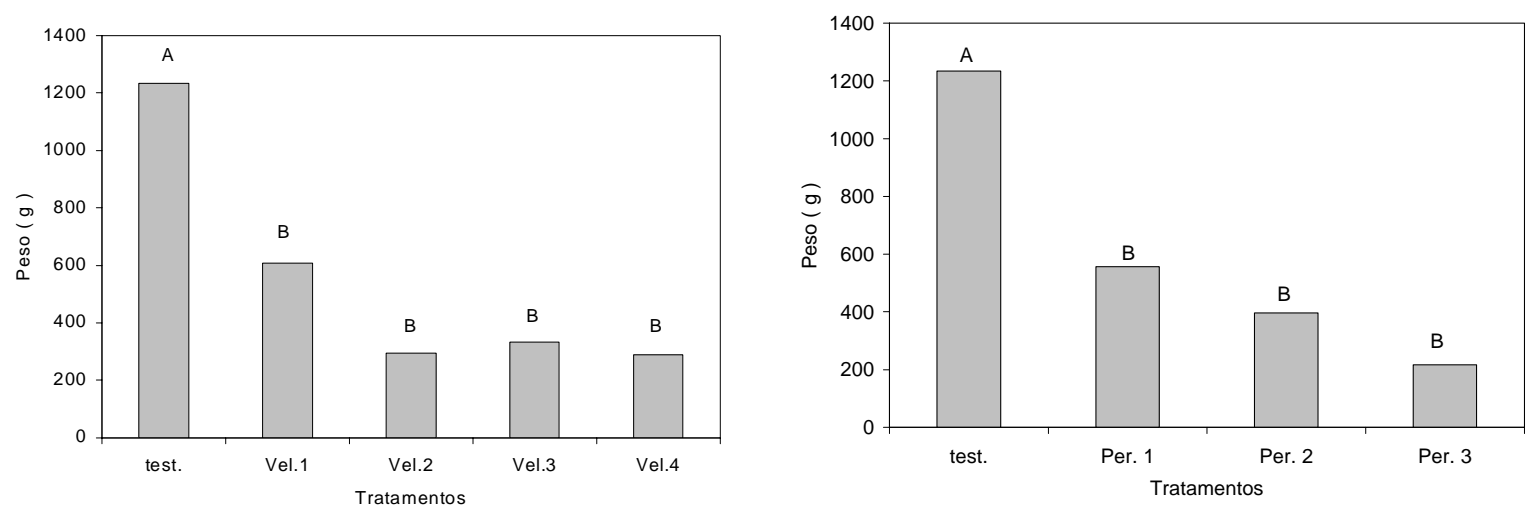

Figura 10 - Médias do peso verde de tubérculos sadios graúdos (diâmetro mínimo > $45 \mathrm{~mm})$, por planta de batata, segundo os diferentes tratamentos

número de tubérculos, ou seja, o peso médio dos tubérculos graúdos praticamente não foi afetado pelos tratamentos.

A Figura 11 apresenta o peso médio dos tubérculos sadios da classe $<20 \mathrm{~mm}$, segundo os diferentes tratamentos. Observa-se que o teste de Duncan não foi capaz de apontar as diferenças significativas reveladas no teste F. Entretanto, verifica-se uma tendência de haver um aumento do peso com a diminuição das velocidades de rebaixamento. Uma análise mais detalhada desta fração revela que este aumento deve-se mais a um crescimento do número do que do peso médio dos tubérculos desta classe. Por outro lado, além de não se tratar de uma classe com interesse comercial, pois os tubérculos são excessivamente pequenos, a contribuição desta fração no peso verde dos tubérculos sadios é pouco significativa, variando de 0,7 para a testemunha a 3,7\% para V4.

\subsubsection{Relação entre a produtividade relativa da cultura da batata e o índice diário de estresse (IDS)}

Os valores dos coeficientes de sensibilidade da cultura (SC) calculados pela equação 2 traduzem de forma numérica o efeito dos períodos de aplicação do 

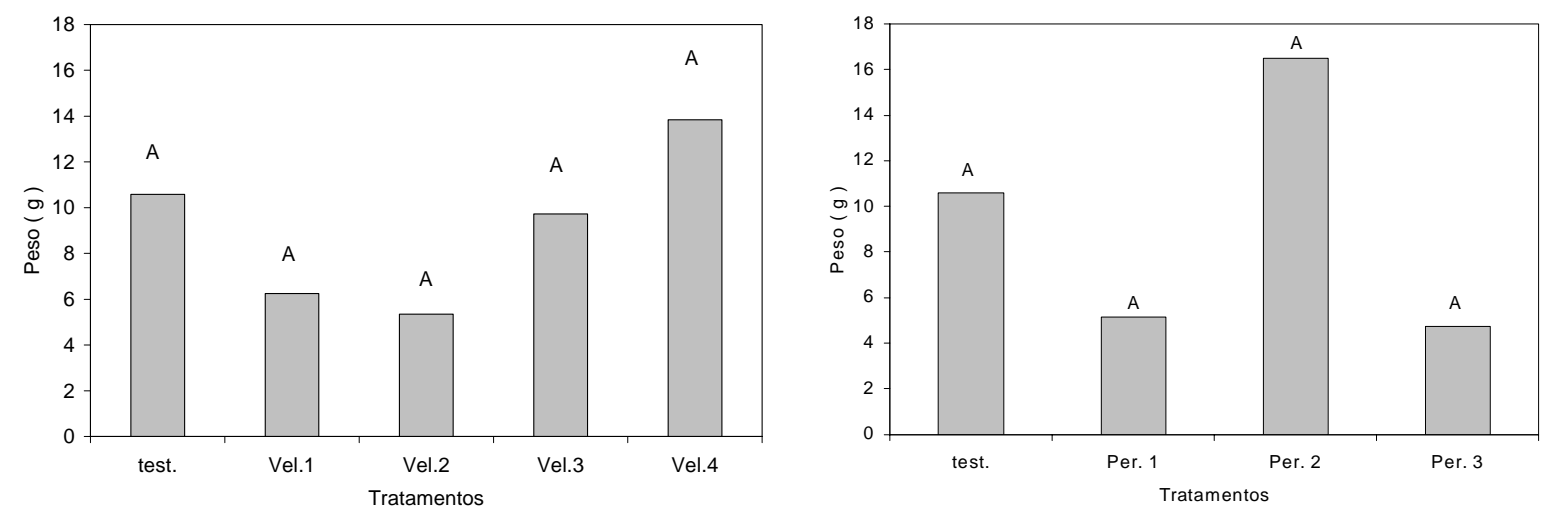

Figura 11 - Médias do peso verde de tubérculos sadios com diâmetro mínimo $<20 \mathrm{~mm}$, por planta de batata, segundo os diferentes tratamentos

encharcamento sobre o decréscimo da produtividade comercial da cultura da batata. Os valores de SC são maiores nos períodos mais críticos.

O coeficiente SC para o primeiro estádio foi o menor dentre os três estádios, atingindo o valor médio de 0,53 e apresentando variações de 0,47 a 0,59. No segundo estádio, SC variou de 0,36 a 0,90, sendo neste estádio, SC médio igual a 0,69. No terceiro estádio, SC apresentou seu maior valor, variando de 0,59 a 0,84, sendo, neste estádio, SC médio igual a 0,77. Estes resultados revelam que a quebra na produção comercial devido aos encharcamentos proporcionados no $1^{\circ}, 2^{\circ}$ e $3^{\circ}$ períodos foram, em média, de 53, 69 e 77\%, respectivamente.

A Figura 12 apresenta a regressão entre a produtividade relativa, calculada em função da produtividade comercial e o índice diário de estresse (IDS). O modelo linear foi o que apresentou melhor ajuste, o que está em concordância com trabalhos realizados com outras culturas como a soja (Scott et al., 1989), milho (Mukhtar et al., 1990), cenoura (Vildoso, 1995) e ervilha (Sá, 2002).

A reta pontilhada representa aquela que fornece o maior coeficiente de determinação $\left(\mathrm{R}^{2}\right)$. Segundo a equação desta reta, para um valor nulo de IDS (ausência total de estresse), obtém-se uma produtividade relativa de apenas 80,884 \%, o que não está de acordo com o modelo proposto por Hiler (1969). Impondo-se a condição da reta passar pelo ponto correspondente à testemunha [IDS=0; YT=100\%], obtém-se uma segunda 


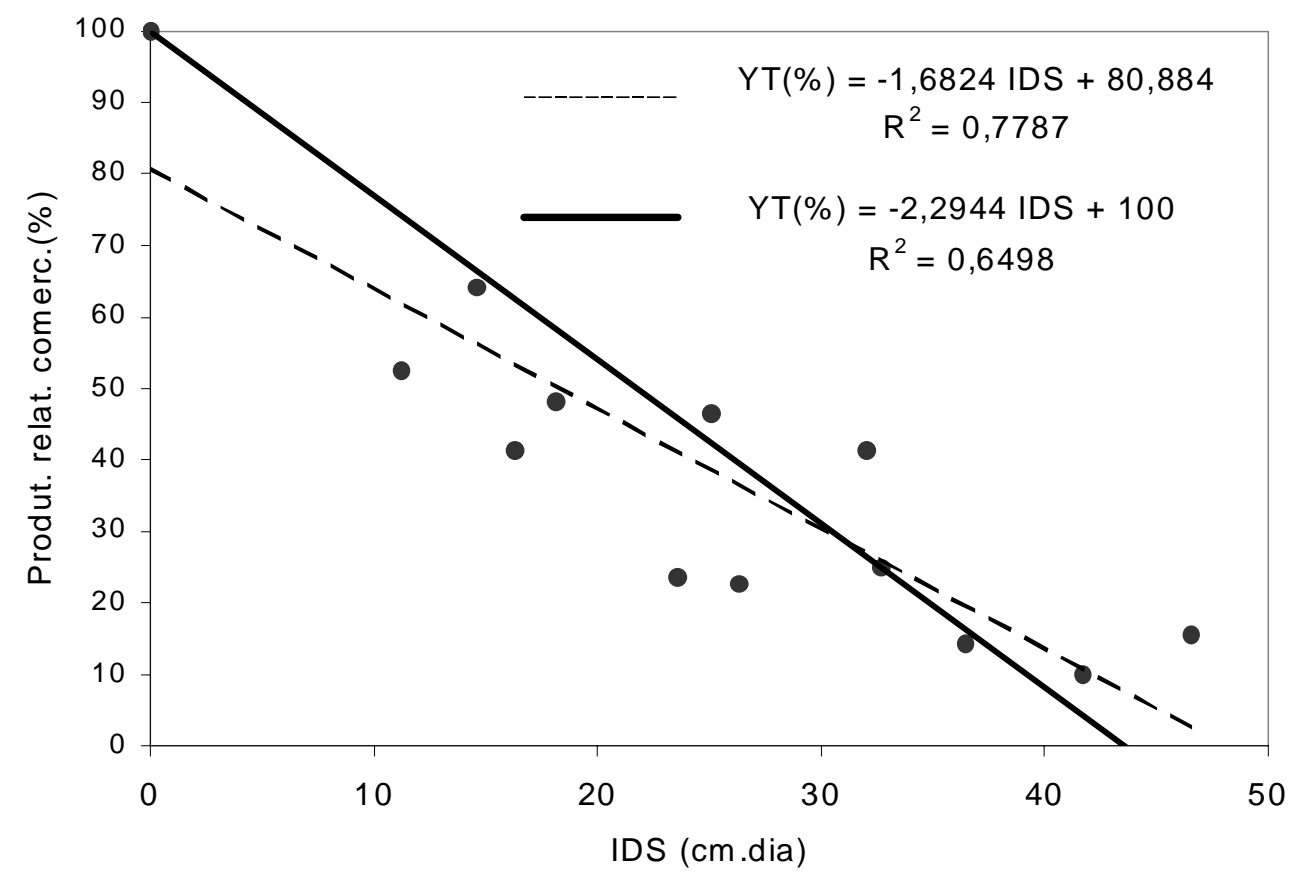

Figura 12 - Produtividade comercial relativa da batata (YT) relacionada ao índice diário de estresse (IDS)

equação (YT= - 2,2944 IDS + 100), que embora possua $\mathrm{R}^{2}$ mais baixo $(0,6498)$, pode ser utilizada como uma primeira aproximação por modelos de simulação de desempenho de sistemas de drenagem, para o dimensionamento de projetos nos quais a batata seja uma das culturas de interesse.

\subsection{Experimento com a cultura da alface}

\subsubsection{Parâmetros climáticos medidos ao longo do ciclo da alface}

O plantio das mudas de alface foi realizado no dia 8 de dezembro de 2001, sendo a colheita efetuada no dia 17 de janeiro de 2002, ou seja, 41 dias após o plantio. Na Tabela 13 são apresentados os dados climáticos medidos durante este período no Posto Meteorológico do Departamento de Ciências Exatas da ESALQ/USP. 
Tabela 13. Parâmetros climáticos medidos durante o ciclo da cultura da alface

\begin{tabular}{lc}
\hline Parâmetro & Valor medido \\
\hline Temperatura máxima média $\left({ }^{\circ} \mathrm{C}\right)$ & 29,0 \\
Temperatura mínima média $\left({ }^{\circ} \mathrm{C}\right)$ & 19,2 \\
Temperatura média $\left({ }^{\circ} \mathrm{C}\right)$ & 24,1 \\
Umidade relativa média $(\%)$ & 87,8 \\
Precipitação total $(\mathrm{mm})$ & 374,0 \\
Evaporação total $(\mathrm{mm})$ & 224,1 \\
\hline
\end{tabular}

Os dados da série histórica completa do Posto Meteorológico da ESALQ/USP (1917 a 2003), para os meses de dezembro e janeiro, revelam dados médios de temperatura máxima, mínima e média de 29,6 e 29,3; 18,2 e 18,5; 23,9 e 23,9; respectivamente. Desta forma, verifica-se que em relação às temperaturas, o período compreendido pelo ciclo da alface foi bastante típico. No que diz respeito às precipitações, a série histórica apresenta valores médios de 6,5 e 7,1 $\mathrm{mm} \mathrm{d}^{-1}$, para os meses de dezembro e janeiro, respectivamente. O valor médio observado ao longo dos 41 dias do ciclo foi de 9,1 $\mathrm{mm} \mathrm{d}^{-1}$, ou seja, foi um período relativamente mais chuvoso que o normal, o que ocasionou a perda de algumas mudas. Como consequência das chuvas abundantes, a umidade relativa média observada no período $(87,8 \%)$ revelou-se acima da média histórica, que para os meses de dezembro e janeiro é de 74,8 e 74,3\% respectivamente.

\subsubsection{Variáveis fenológicas e produtividade da alface}

O resultado da análise da variância de todas as variáveis analisadas para a cultura da alface está apresentado de forma resumida na Tabela 14, onde se pode observar que não houve nenhuma variável que apresentou a interação velocidade x período com um valor $\mathrm{F}$ significativo em nível de pelo menos $5 \%$ de probabilidade. Verifica-se também que para todas as variáveis analisadas houve diferença entre a testemunha e pelo menos um dos outros tratamentos envolvidos. 
Tabela 14. Valores de F e da probabilidade do efeito ter se dado ao acaso (entre parênteses) para cada variável avaliada no experimento com a alface

\begin{tabular}{cccccc}
\hline \multirow{2}{*}{ Causas de Variação } & \multicolumn{5}{c}{ Variáveis } \\
& Altura & $\begin{array}{c}\text { Diâmetro } \\
\text { da cabeça }\end{array}$ & $\begin{array}{c}\text { Diâmetro do } \\
\text { caule }\end{array}$ & $\begin{array}{c}\text { Peso verde da } \\
\text { parte aérea }\end{array}$ & $\begin{array}{c}\text { Peso seco da } \\
\text { parte aérea }\end{array}$ \\
\hline Testemunha vs to- & $10,52 * *$ & $12,05 * *$ & $6,21 *$ & $26,68 * *$ & $30,86 * *$ \\
dos & $(0,0033)$ & $(0,0019)$ & $(0,0197)$ & $(<0,0001)$ & $(<0,0001)$ \\
Velocidade & 2,56 & 1,59 & $3,54 *$ & 2,07 & 2,07 \\
Período & $(0,0777)$ & $(0,2171)$ & $(0,0291)$ & $(0,1301)$ & $(0,1295)$ \\
Interação velocida- & $9,15 * *$ & 3,72 & $5,95 * *$ & $5,74 * *$ & $8,77 * *$ \\
de*período & $(0,0010)$ & $(0,8903)$ & $(0,0077)$ & $(0,0089)$ & $(0,0013)$ \\
\hline
\end{tabular}

* - Significativo em nível de 5\% de probabilidade.

** - Significativo em nível de $1 \%$ de probabilidade.

No que diz respeito ao fator período, somente para a variável diâmetro da “cabeça” não se obteve um valor de F que não fosse significativo a 1\% de probabilidade. Já para o fator velocidade, só foram encontradas diferenças significativas para a variável diâmetro do caule.

Os valores das médias das variáveis analisadas são apresentados na forma de gráficos (Figuras 13, 14, 15, 16 e 17). Nestes gráficos as letras sobre as colunas representam o resultado do teste de comparação de médias de Duncan, realizado a 5\% de significância dentro de cada fator (períodos e velocidades) isoladamente, pois as interações entre os fatores não foram significativas.

Observando-se os resultados do teste de comparação de médias de Duncan para a variável altura da parte aérea, apresentado na Figura 13, pode-se avaliar que houve diferença significativa entre a testemunha e os tratamentos relativos às velocidades de rebaixamento mais lentos (V3 e V4) e entre esta e os tratamentos aplicados no primeiro período. Quando se compara os três períodos, independentemente da testemunha, o teste de Duncan não consegue acusar diferenças, embora estas tenham sido identificadas no teste F. Conforme relatado na discussão do experimento com a batata, isto possivelmente ocorre devido ao fato das diferenças entre a média do fatorial e a média 

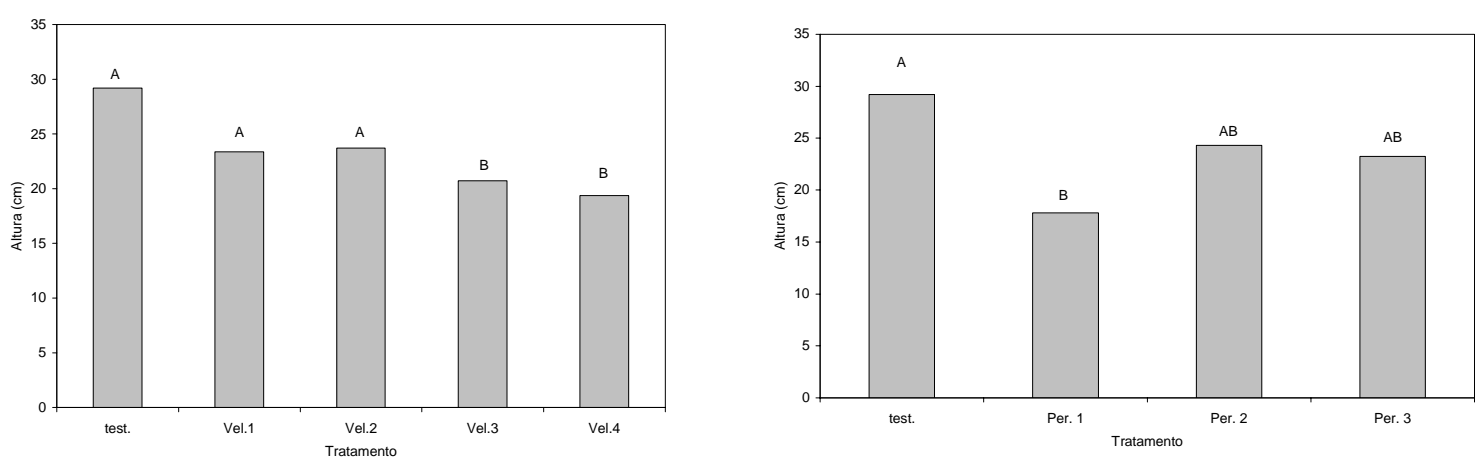

Figura 13 - Médias da altura da parte aérea das plantas de alface segundo os diferentes tratamentos

da testemunha serem muito discrepantes, ocasionando uma diferença significativa no teste F.

Quanto à variável diâmetro da "cabeça”, cujas médias são apresentadas na Figura 14, pode-se observar que a testemunha forneceu valor significativamente maior que os tratamentos que sofreram encharcamento. Entretanto, não é possível se identificar tendências relativas às diferentes velocidades ou períodos, o que está em concordância com os resultados do teste $\mathrm{F}$.
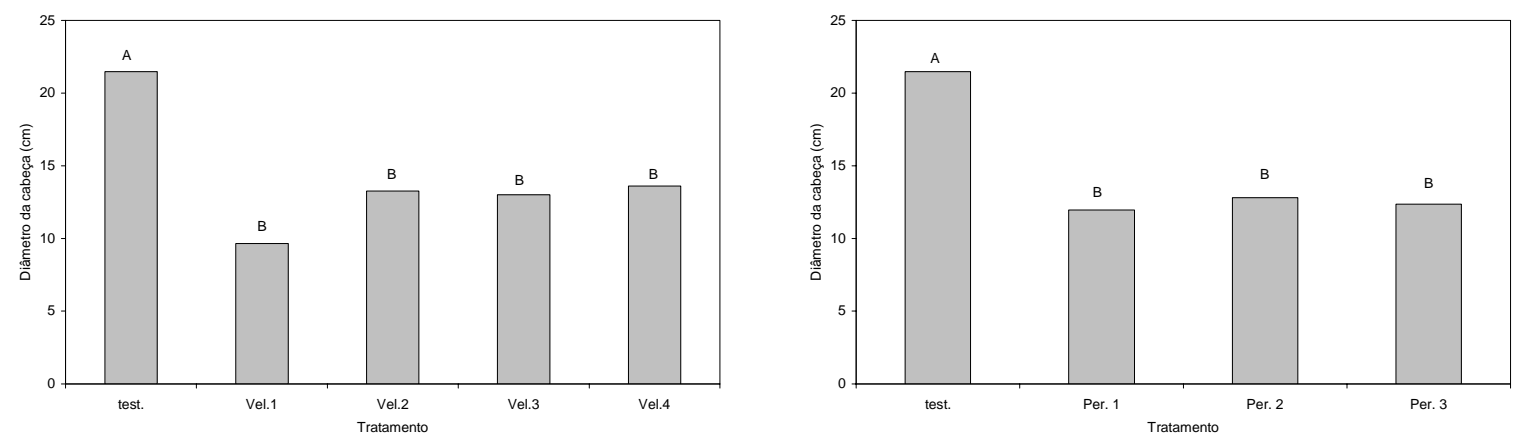

Figura 14 - Médias do diâmetro da ‘cabeça' das plantas de alface segundo os diferentes tratamentos 
A Figura 15 apresenta o resultado do teste de comparação de médias de Duncan para a variável diâmetro do caule. Esta variável apresenta-se um pouco menos sensível às diferentes velocidades de rebaixamento do que a variável altura da parte aérea (Figura 13), pois a testemunha só difere significativamente de V4. O período P1, tal como verificado na Figura 13, demonstra ser o mais crítico. Observa-se ainda que o teste de Duncan não foi capaz de revelar as diferenças entre as quatro velocidades e os três períodos, muito embora estas tenham sido apontadas pelo teste $\mathrm{F}$.
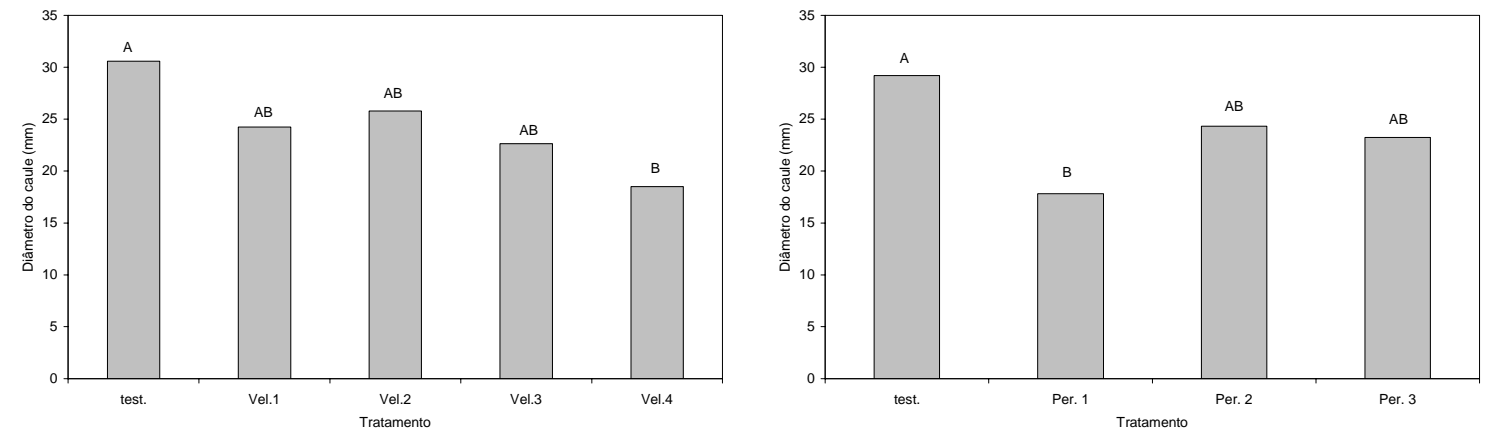

Figura 15 - Médias do diâmetro do caule das plantas de alface segundo os diferentes tratamentos

O resultado dos tratamentos sobre a variável peso ‘verde’ da parte aérea é apresentado na Figura 16. Pode-se observar que o efeito dos tratamentos sobre esta variável são mais drásticos, ou seja, a testemunha difere significativamente de todos os tratamentos relativos às velocidades e períodos. Considerando-se que esta seja a variável mais importante, verifica-se que mesmo com a velocidade de rebaixamento mais alta (V1 = $30 \mathrm{~cm}$ em 1 dia) o peso fresco da parte aérea foi cerca de metade do peso da testemunha, o que está em concordância com Cruciani \& Minami (1982) que relataram a grande sensibilidade das hortaliças ao encharcamento. Estudando a suscetibilidade do pimentão a inundações temporárias do solo, estes autores encontraram que o tempo de drenagem da zona radicular deve ser inferior a 2 dias. Para a cultura da alface, portanto, há a necessidade de se testar velocidades de rebaixamento ainda maiores para se definir o valor do coeficiente de drenagem. Embora o teste de Duncan não revele diferenças entre 
os períodos de aplicação, diferença esta acusada no teste $\mathrm{F}$, verifica-se que o período 1 apresenta-se como o mais crítico, tal como foi observado para a altura da parte aérea e o diâmetro do caule.
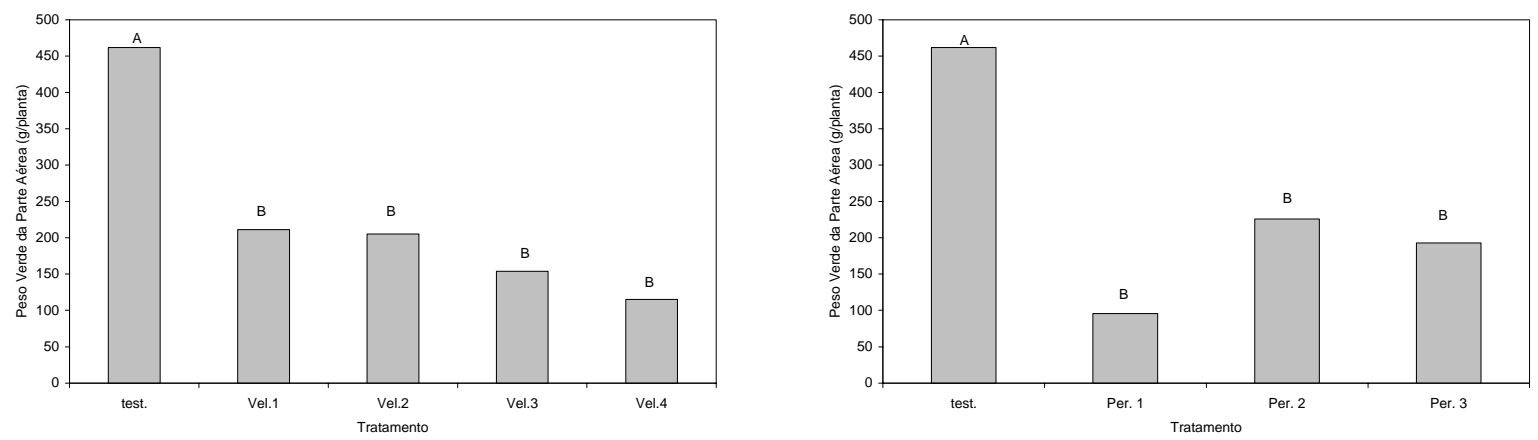

Figura 16 - Médias do peso verde da parte aérea das plantas de alface segundo os diferentes tratamentos

As médias do peso seco da parte aérea para os diferentes tratamentos são apresentadas na Figura 17. Como esperado, a tendência é a mesma observada para a variável peso verde. Os menores valores observados para os tratamentos aplicados no período 1 estão em concordância com os resultados observados por Vildoso (1995) para a cultura da cenoura.
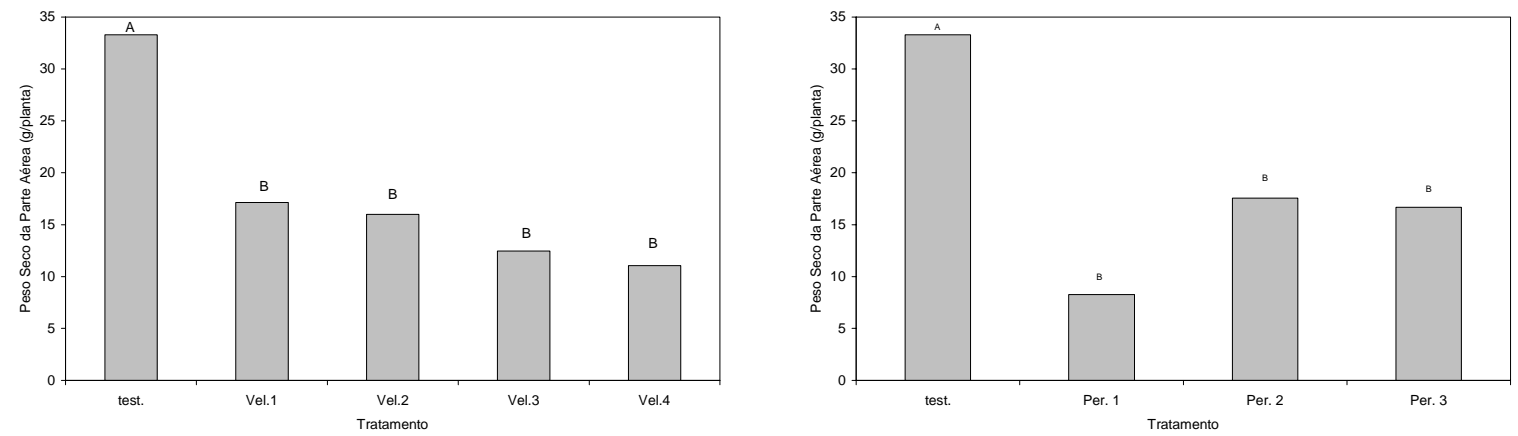

Figura 17 - Médias do peso seco da parte aérea das plantas de alface segundo os diferentes tratamentos 
A grande sensibilidade ao encharcamento revelada para as culturas da alface e da batata, mesmo para condições em que o nível freático é rebaixado rapidamente (V1), leva a supor que, quando possível, evitar que o lençol atinja a superfície do solo após uma recarga intensa, com o plantio sobre canteiros, leiras ou camalhões, pode se apresentar como uma boa opção prática.

\subsubsection{Relação entre a produtividade relativa da cultura da alface e o índice diário de estresse (IDS)}

Tal como relatado para a cultura da batata, os valores dos coeficientes de sensibilidade da cultura da alface (SC) calculados pela equação 2, traduzem de forma numérica o efeito dos períodos de aplicação do encharcamento apresentados na Figura 16, sendo que estes são maiores nos períodos mais críticos. O coeficiente SC médio para o primeiro estádio foi de 0,79 e apresentou variações de 0,61 a 0,90. No segundo estádio, SC variou de 0,37 a 0,71, sendo, neste estádio, SC médio igual a 0,51. No terceiro estádio, SC variou de 0,53 a 0,64, sendo, neste estádio, SC médio igual a 0,58. Estes resultados revelam que a quebra de produção devido aos encharcamentos proporcionados no $1^{\circ}, 2^{\circ}$ e $3^{\circ}$ períodos foram, em média, de 79, 51 e 58\%, respectivamente.

A Figura 18 apresenta a regressão entre a produtividade relativa e o índice diário de estresse (IDS), onde o modelo linear foi o que apresentou melhor ajuste, tal como ocorreu com a cultura da batata.

A reta pontilhada representa aquela que fornece o maior coeficiente de determi-

nação $\left(\mathrm{R}^{2}\right)$. Segundo a equação desta reta, para um valor nulo de IDS (ausência total de estresse), obtém-se uma produtividade relativa de apenas 79,877\%, o que não está de acordo com o modelo proposto por Hiler (1969). Impondo-se a condição da reta passar pelo ponto correspondente à testemunha [IDS=0; YT=100\%], obtém-se uma segunda equação (YT= 100 - 2,9797 IDS), que embora possua $\mathrm{R}^{2}$ mais baixo $(0,5807)$, pode ser utilizada por modelos de simulação, tal como a equação obtida para a cultura da batata, como uma primeira aproximação de dimensionamento de sistemas de drenagem, para projetos nos quais a alface seja uma das culturas de interesse. 


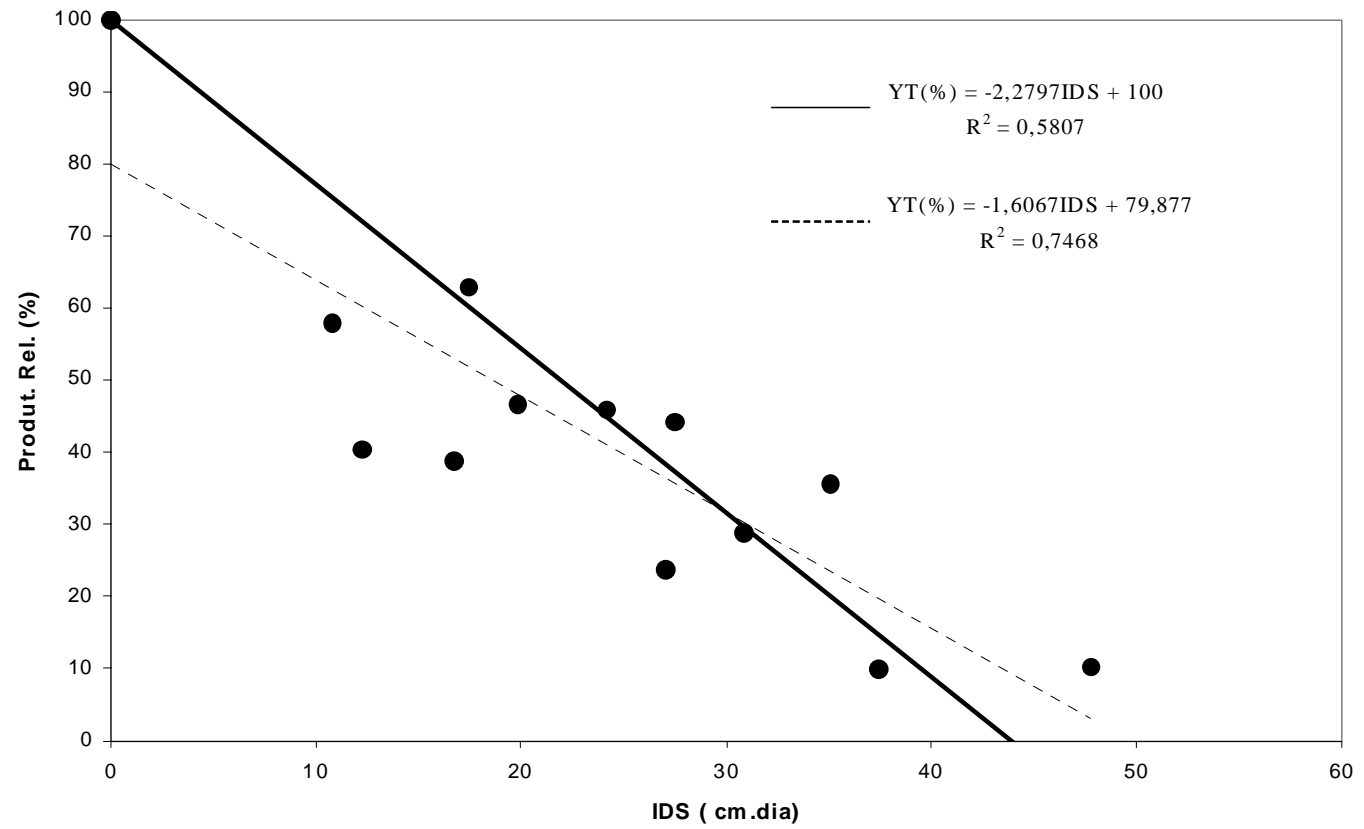

Figura 18 - Peso verde relativo da parte aérea da alface (YT) relacionado ao índice diário de estresse (IDS) 


\section{CONCLUSÕES}

Considerando as condições em que os experimentos realizados com as culturas da batata e da alface foram conduzidos, os resultados obtidos permitiram concluir que:

- Dentre os três períodos nos quais os estresses causados pela elevação do nível freático foram aplicados, o que ocasionou maiores perdas para a cultura da batata foi o terceiro, aplicado do $85^{\circ}$ ao $88^{\circ}$ dia após o plantio. Já para a cultura da alface, o período mais crítico foi o primeiro, aplicado do $12^{\circ}$ ao $15^{\circ}$ dia após o transplantio.

- As duas culturas apresentaram-se bastante sensíveis ao encharcamento, não sendo possível se definir valores adequados para os coeficientes de drenagem, pois mesmo com a maior velocidade de rebaixamento do nível freático ( $30 \mathrm{~cm}$ em 24 horas ) houve decréscimos de cerca de $50 \%$ da produtividade para ambas as culturas.

- As produtividades relativas das plantas de ambas as culturas apresentaram correlacões lineares negativas com o índice diário de estresse devido ao excesso de água no solo.

- No que se refere à cultura da batata, o encharcamento causou redução tanto no peso médio quanto no número de tubérculos por planta, sendo a classe comercial graúda a mais afetada. Verificou-se também aumento de incidência de doenças e distúrbios fisiológicos nos tubérculos devido ao excesso de umidade do solo.

- Já para a cultura da alface, os efeitos do encharcamento puderam ser identificados pela redução da altura, do diâmetro e do peso da parte aérea, além da redução do diâmetro do caule, sendo a variável peso da parte aérea a que apresentou maior sensibilidade. 


\section{REFERÊNCIAS BIBLIOGRÁFICAS}

AHMAD, N.; KANWAR, R. S. Crop susceptibility factors of corn and their effect on stress-day index. Transactions of the ASAE, v.32, n.6, p.1979-1986, 1989.

BACHA, R. E. Princípios Básicos para a adubação de arroz irrigado. In: BACHA, R.E. Curso Nacional da Cultura do Arroz irrigado, 1. Araranguá: Embrapa-Acaresc, 1987, $14 \mathrm{p}$.

BAVER, L. D.; GARDNER, W. H.; GARDNER, W. R. Soil physics. 4 ed. New York: John Wiley, 1972. 498 p.

Beltrán, J. M. Drenaje Agrícola. Madrid: Ministerio de Agricultura Pesca y Alimentación. Cidade; Instituto Nacional de Reforma y Desarrollo Agrario, 1986. 239p. (Manual Técnico, 5).

BOUWER, H. Developing drainage design criteria. In: SCHILFGAARDE, J. van Drainage for agriculture. Madison: American Society of Agronomy, 1974. p.6790.

CANNEL, R. Q.; JACKSON, M. B. Alleviating aeration stress. In: ARKING, G.F.; TAYLOR, H. M. Modifying the root enviroment to reduce crop stress. St. Joseph: American Society of Agricultural Engineers, 1981, p.141-180. 
CARTER, C. E.; BENGTSON, R. L.; ROGERS, J. S. Drainage needs as indicated by high water tables. Transactions of the ASAE, v.31, n.5, p.1410-1415, 1988.

CARTER, C. E.; WRATTEN, F.T.; MAC DANIEL, V.; HALVERSON, B. Hydraulic conductivity measured electronically in an auger hole. Transactions of the ASAE, v.27, n.5, p.1400-1404, 1984.

COELHO, E. F.; FILHO, J. C.; CARVALHO, J. P. de.; CUPERTINHO, J. L.; CAMPOS, D. G. Drenagem de várzeas. Informe Agropecuário, v.13, n.151, p.23-35, 1988.

COSTA, R. N. T. Espaçamento econômico de drenos laterais e a dinâmica do lençol freático sobre o rendimento da cultura do milho (Zea mays L.). Piracicaba, 1994. 88p. Tese (Doutorado) Escola Superior de Agricultura “Luiz de Queiroz”, Universidade de São Paulo.

COSTA, R.N.T.; VASCONCELOS, J.P.; SILVA, L.A.; NESS, R.L.L. Efeitos do excesso de água no solo sobre componentes de produção da beterraba (compact disc). IN: CONGRESSO BRASILEIRO DE ENGENHARIA AGRÍCOLA, 32., Goiânia, 2003. CONBEA2003. Goiânia: Sociedade Brasileira de Engenharia Agrícola. 2003.

CRUCIANI, D. E. Caracterização de coeficientes de drenagem com base nos parâmetros de produção das culturas. Piracicaba, 1981a. 99 p. Tese (Livre Docência) Escola Superior de Agricultura “Luiz de Queiroz”, Universidade de São Paulo.

CRUCIANI, D. E. Caracterização agronômica de coeficientes de drenagem para elaboração de projetos. In: SIMPÓSIO BRASILEIRO DE HIDROLOGIA E RECURSOS HÍDRICOS, 4., Fortaleza, 1981. Anais. Fortaleza: Associação Brasileira de Recursos Hídricos - ABRH, 1981b. p.500-514. 
CRUCIANI, D. E. Caracterização agronômica do coeficiente de drenagem para elaboração de projetos com a cultura do milho (Zea mays, L.) Revista ITEM, v.22, p. 2831, 1985.

CRUCIANI, D. E. A drenagem na agricultura. 2.ed. São Paulo: Nobel, 1987. 337p.

CRUCIANI, D. E.; MINAMI, K. Susceptibilidade do pimentão (Capsicum annum, L.) a inundações temporárias do sistema radicular. Anais da Escola Superior de Agricultura “Luiz de Queiroz”, v.39, p.137-150, 1982.

CRUCIANI, D. E.; MINAMI, K. Efeitos do excesso de água no solo na produção de aveia (Avena strigosa sckreb). Revista ITEM, v.16, p.31-33, 1984.

CURI, N., RESENDE, M., SANTANA, D. P. Solos de várzeas de Minas Gerais. Informe Agropecuário, v.13, n.152, p.3-10, 1988.

DUARTE, S. N. Efeitos do horário e da lâmina de irrigação na cultura da batata (Solanum tuberosum L.). Piracicaba, 1989. 148p. Dissertação (Mestrado) - Escola Superior de Agricultura “Luiz de Queiroz”, Universidade de São Paulo.

DUARTE, S. N. ; FERREIRA, P. A.; PRUSKI, F. F.; MARTINEZ, M. A. Modelo para avaliação de desempenho de sistemas de drenagem subterrânea e cálculo de espaçamento de drenos. Parte 1: desenvolvimento e análise de sensibilidade. Engenharia Agrícola, v.18, n.2, p.19-31, 1998.

EMPRESA BRASILEIRA DE ASSISTÊNCIA TÉCNICA E EXTENSÃO RURAL. Manual técnico da cultura da batata. Brasília: Ministério da Agricultura, 1982. 234p. (Manuais, 23). 
FAO. Yield response to water. Rome: Food and Agriculture Organization of the United Nations. 1979. 193p. (Irrigation and Drainage Paper , 33).

FAO. Drainage design factors. Rome: Food and Agriculture Organization of the United Nations. Rome, 1980. 117p. (Irrigation and Drainage Paper, 26).

FARIAS, M. S. S. Diagnostico da necessidade de drenagem na Estação Experimental de São Gonçalo. Campina Grande, 1996. 30 p. Monografia ( Graduação ) - Faculdade de Engenharia, Universidade Federal da Paraíba.

FERREIRA, P. A. Drenagem. Brasilia: ABEAS, 1987. 86p. (Modulo 11).

GAYLE, G. A.; SKAGGS, R. W.; CARTER, C. E. Effects of excessive soil water conditions on sugarcane yields. Transactions of the ASAE, v.30, n.4, p.993-997, 1987.

GENUCHTEN, M. T. van. A closed-form equation for predicting hydraulic conductivity of unsaturated soils. Soil Science Society American Journal, v.44, n.3, p.892-898, 1990.

GOOR, G. A. W. van de. Desarrollo de las plantas en relación con el drenaje. In: GOOR, G. A. W. van de. Drainage principles and application. Wageningen: International Institute for land Reclamation Improvement (ILRI), 1980. v.1, p.99134.

HARDJOAMIDJOJO, S.; SKAGGS, R. W.; SCHWAB, G. O. Corn yield response to excessive water conditions. Transactions of the ASAE, v.25, n.4, p.922-927, 934, 1982. 
HARRIS, C. I.; ERICSON, H. T.; ELLIS, M. K.; LARSON, J. E. Water level control in organic soil, as related to subsidence rate, crop yield and response to nitrogen. Soil Science, v.94, p.158-161. 1962.

HILER, E.A. Quantitative evaluation of crop drainage requirements. Transactions of the ASAE, v.12, n.4, p.499-505, 1969.

HILER, E. A.; CLARK, R. N. Stress day index to characterize effects of water stress on crop yields. Transactions of the ASAE, v.14, n.4, p.757-761, 1971.

HOORN, J. W. van. Results of a ground water level experimental field with arable crops on clay soil. Netherlands Journal of Agricultural Science, v.6, n.1, p.1-10, 1958.

KANDIL, H. M., WILLIARDSON, L. S. Relating crop yield response to water table fluctuations. Journal Irrigation Drainage Engineering, v.118, p.113-121, 1992.

KANWAR, R. S. Stress-day factor and stress day index as indicators of drainage needs of the soil. Transactions of the ASAE, v.31, n.5, 1423-1429, 1988.

KANWAR, R. S.; BAKER, J. L.; MUKTHAR, S. Excessive soil water effects at various stages of development on growth and yeild of corn. Transactions of the ASAE, v.31, n.1, p.133-141, 1988.

KLAMT, E.; KAMPF, N.; SCHNEIDER, P. Solos de várzeas no Estado do Rio Grande do Sul. Porto Alegre: Universidade Federal do Rio grande do Sul, Faculdade de Agronomia, Departamento de Solos, 1985. 43p.

KOZLOWSKI, T. T. Water deficit and plant growth. New York: Academic Press. cap.4, 1976. p.191-233. 
KRAMER, P. S. Causes of injury to plants resulting from flooding of the soil. Plant Physiology. v.26, p.722-736, 1951.

KRAMER, P. S. Plant and water relationships. A modern synthesis. New York: McGraw Hill Book, 1969. 482 p.

LANGE, O. L. Flora, v.140, p.39-97, 1953.

LIMA, C. A. S.; FERREIRA, P. A.; CAIXETA, T. J.; LOUREIRO, B. T. Efeito da profundidade do lençol freático como fonte de suprimento de água à cultura do feijão. In: CONGRESSO NACIONAL DE IRRIGAÇÃO E DRENAGEM, 7., Brasília, 1986. Anais. Brasília: Associação Brasileira de Irrigação e Drenagem - ABID, 1986. v. 2, p.567-584.

LUTHIN, J. N. Drainage Engineering. New York: Robert E. Krieger Pub. Huntington, 1973. 250 p.

MEYER, B. C., ANDERSON D. B. Introduction to Plant Ecology. New Jersey, Princeton: Nostrand Company, 1960. 217p.

MILLAR, A. A. Drenagem de terras agrícolas: bases agronômicas. São Paulo: McGraw-Hill do Brasil, 1978. 276p.

MIRANDA, J. H. Modelo para simulação da dinâmica de nitrato em colunas verticais de solo não saturado. Piracicaba, 2001. 79p. Tese (Doutorado) Escola Superior de Agricultura “Luiz de Queiroz”, Universidade de São Paulo.

MIRANDA, J. H.; DUARTE, S. N.; FOLEGATTI, M. V. Modelo para simulação da dinâmica da água em sistemas de drenagem subterrânea. Engenharia Rural. Piracicaba: Departamento de Engenharia Rural - ESALQ/USP, v.9, n.2, p.1-10, 1998. 
MUKHTAR, S.; BAKER, J. L.; KANWAR, R. S. Corn growth as affected by excess soil water. Transactions of the ASAE, v.33, n.2, p.437-442, 1990.

NOBEL, P. S. Introduction to biophysical plant ecology. San Francisco: Freeman, 1974. $480 \mathrm{p}$.

OBREZA, T. A.; YAMATAKI L.; PEARLSTINE, G. Classification of land suitability for citrus production using Drainmod. Journal of Soil and Water Conservation, v.48, n.1, p.58-64, 1993.

PATWARDHAN, A. S. ; NIEBER, J. L.; MOORE, I. D. Oxigen, carbon dioxide and water transfer in soils mechanisms and crop response. Transactions of the ASAE, v.31, n.5, p.1383-1395, 1988.

PIZARRO, F. Drenaje Agrícola y recuperación de suelos salinos. Madrid: Editorial Agrícola Española, 1978. 521 p.

REICHARDT, K. Processos de transferência no sistema solo-planta-atmosfera. 4 ed. Campinas: Fundação Cargil, 1985. 466 p.

ROBERTS, J. W. J. Geophysics Research, v.66, p.3308-3312, 1961.

ROJAS, R. M. Drenaje Superficial de tierras agrícolas. Brasilia: Centro Interamericano de Desarrollo Integral de Aguas y tierras, 1984. 95 p.

RYDER, E. J. Leafy salad vegetables. Westport: AVI Publishing, 1979. 266 p. 
SÁ, J. S.; CRUCIANI, D. E.; DUARTE, S. N. Índice diário de estresse hídrico da cultura de ervilha (compact disc). CONGRESSO NACIONAL DE IRRIGAÇÃO E DRENAGEM, 12., Uberlândia, 2002. CONIRD. Brasília: Associação Brasileira de Irrigação e Drenagem - ABID, 2002.

SCHILGAARDE, J. van. Nonsteady flow to drains In: SCHILFGAARDE, J. van. Drainage for agriculture. Madison: American Society of Agronomy, 1974. p.245270.

SCHILFGAARDE, J. van.; WILLIAMSOM, P. E. Studies of crops response to drainage growth chambers. Transaction of the ASAE. v.8, p.94-97, 1965.

SCHWAB, G. O.; MANSON, P. W.; LUTHIN, J. N.; REEVE, R. C.; EDMISTER, T. W. Engineering aspects of land drainage; drainage in humid areas. In: LUTHIN, J. L. Drainage of a agricultural lands. Wisconsin: American Society of Agronomy, 1977. p.167-187.

SCOTT, H. D.; DE ANGULO, J; DANIELS, M. B.; WOOD, L. S. Flood duration effects on soybean growth and yield. Agronomy Journal, v. 81, p. 631-636, 1989.

SILVA, A. S. O Pro-Várzeas em propriedades selecionadas do município de CurveloMG. Viçosa, 1982. 77p. Dissertação (Mestrado) - Universidade Federal de Viçosa.

SKAGGS, R. W. DRAINMOD - Reference report: methods for design and evaluation of drainage-water management systems for soils with high water tables. Raleigh: USDA-SCS, 1981. 329p.

SKAGGS, R. W. DRAINMOD - User's manual. Raleigh: North Caroline State University, 1990. 101p. 
TOVEY, R. Alfalfa growth as influenced by static and fluctuating water tables. Transaction of the ASAE, v.7, n.3, p.330-332, 1964.

VILDOSO, T. A. Relação entre a produção relativa e o índice diário de stress para a cultura da cenoura (Daucus carota L.) Viçosa, 1995. 43p. Dissertação (Mestrado) Universidade Federal de Viçosa.

WESSELING, J. Crop growth and wet soils. In: SCHILFGAARDE, J. van. Drainage for agriculture. Madison: American Society of Agronomy, 1974. p.7-37. (Agronomy, 17).

WILLIAMSON, R. E. The effect of root aeration on plant growth. Soil Science Society American Proceedings, v.28, p.86-90, 1964.

WILLIAMSOM, R. E. Effects of soil gas composition and flooding on growth of (Nicotiana tabacum, L). Agronomy Journal, v.62, p.80-83, 1970.

WILLIAMSOM, R. E. , KRIZ, G. J. Response of agricultural crops to flooding depth of water table and soil gaseous compositions. Transaction of ASAE, v.13, n.3, p.216220, 1970.

WOUDT, D. van't, HAGAN, R. M. Crop response at excessively high soil moisture levels. In: LUTHIN, J. N. Drainage of agricultural lands. Madison: American Society of Agronomy, 1967. p.514-578. (Monograph, 7) 